\title{
Domestic Courts and Global Governance
}

\author{
Christopher A. Whytock*
}

\begin{abstract}
Domestic court decisions often make headlines around the world. For example, recent United States Supreme Court decisions about the International Court of Justice and the rights of foreign detainees held by the United States at Guantanamo Bay have attracted international attention. However, the role of domestic courts in the world extends far beyond headlines. Seemingly routine decisions on issues such as personal jurisdiction, forum non conveniens, choice of law, extraterritoriality, and arbitration have implications for global governance. Legal scholarship divides these issues into doctrinal categories like civil procedure, conflict of laws, and international law. But by doing so, it misses the bigger picture: for better or worse, domestic courts are pervasively involved in regulating transnational activity.

This Article cuts across doctrinal categories to provide a systematic analysis of the global impact of domestic courts. It argues that domestic courts perform two global governance functions: they allocate governance authority, and they determine rights and obligations of transnational actors. It shows that these functions matter not only for litigants, but also for global welfare. And it proposes a method to critically evaluate these functions that moves beyond traditional litigant-focused assessments to analysis of the cross-border effects of domestic court decisions. This method will allow scholars and policy makers to develop the empirical foundations needed for the intensifying debate over the proper role of domestic courts in addressing global challenges.
\end{abstract}

I. INTRODUCTION

II. The Global GOVERnANCE FunCtIONS OF DOMESTIC

COURTS

A. Who Governs? Judicial Allocation of Global

Governance Authority.

1. Allocation of Governance Authority Among

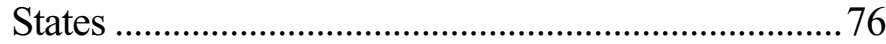

a. Adjudicative Authority ................................77

b. Prescriptive Authority .................................80

c. Enforcement Authority ................................81

* C 2009 Christopher A. Whytock. Associate Professor of Law, University of Utah S.J. Quinney College of Law. Earlier versions of this Article were presented at meetings of the American Society of International Law, the Law and Society Association, the Duke University Seminar on Global Governance and Democracy, and the American Political Science Association. I thank Mark Axelrod, Sam Baumgartner, Christian Ford, Lincoln Davies, Mitu Gulati, Laurence Helfer, Austen Parrish, Matt Pierce, and Jennifer Whytock for valuable comments on earlier versions of this Article; Deborah Avant, Paul Schiff Berman, Tim Büthe, Kevin Clermont, Matt Fehrs, Bruce Jentleson, Judith Kelley, David Klein, Peggy McGuinness, Ralf Michaels, Imke Risopp-Nickelson, Wayne Sandholtz, Jenia Iontcheva Turner, Camber Warren, Melissa Waters, Ashley Williams, and David Zaring for suggestions on related papers in which this Article's themes were developed; Jacob Fonnesbeck and Tara Harrison for research assistance; and Angela Turnbow for help with the manuscript. 
2. Allocation of Governance Authority Between Domestic and International Institutions.

3. Allocation of Governance Authority Between

Private and Public Institutions....

B. Who Gets What? Judicial Determination of Rights

and Obligations of Transnational Actors .............................. 91

1. Transnational Regulatory Litigation .......................... 92

2. Transnational Public Law Litigation............................92

3. Transnational Private Litigation ..................................94

III. THE TRANSNATIONAL SHADOW OF THE LAW .................................96

A. Domestic Courts and the Strategic Behavior of

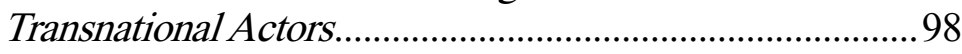

1. Bargaining in the Transnational Shadow of the

Law

2. Transnational Forum Shopping.

100

B. Domestic Courts and the Global Economy....................... 101

C. Domestic Courts and Other Governance Institutions....... 103

1. Domestic Courts and International Institutions......... 104

a. Domestic Courts and the Development

of International Law .....................................104

b. Domestic Courts and Compliance with

International Law ......................................107

c. Domestic Courts and the Effectiveness

of International Courts.................................108

d. The Relationship Between Domestic

Courts and International Institutions ............110

2. Domestic Courts and Transnational Private

Institutions.

a. Domestic Courts and Transnational

Contracting

b. Domestic Courts and Transnational

Arbitration

c. The Relationship Between Domestic

Courts and Transnational Private Institutions

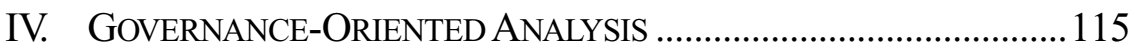

A. Methodological Characteristics ........................................ 115

1. Transnational Law in Action: Governance-

Oriented Analysis as a Complement to

Doctrinal Analysis 
2. The Transnational Shadow of the Law:

Governance-Oriented Analysis as a

Complement to Litigant-Oriented Analysis

B. Descriptive, Positive-Theoretical, and Normative

Goals

V

CONCLUSION

\section{INTRODUCTION}

Domestic court decisions are often world news. The United States Supreme Court decides that a judgment of the International Court of Justice is not binding domestic law, as it did in Medellin $\mathrm{V}$. Texas, ${ }^{1}$ or it decides that noncitizen detainees held by the United States at Guantanamo Bay have rights under the United States Constitution, as it did in Boumediene v. Bush, ${ }^{2}$ and the world pays attention. ${ }^{3}$ But the role of domestic courts in the world extends far beyond headlinecatching decisions like these. Domestic courts routinely make decisions with cross-border implications. Common decisions on issues ranging from personal jurisdiction, forum non conveniens, lis pendens stays, and antisuit injunctions, to choice of law, extraterritoriality, arbitration, foreign judgments, and treaties all have implications for global governance. ${ }^{4}$

Legal scholarship separates issues like these into doctrinal categories, such as civil procedure, international law, conflict of laws, foreign relations law, and arbitration law. ${ }^{5}$ But by doing so, it misses the bigger picture: for better or worse, domestic courts are pervasively involved in the regulation of transnational activity.

\footnotetext{
1. 128 S. Ct. 1346 (2008).

2. 128 S. Ct. 2229 (2008).

3. See, e.g., Corine Lesnes, Les juges réaffirment le droit des prisonniers à se défendre devant la justice civile fédérale, LE MONDE, June 14, 2008, at 4 (reporting United States Supreme Court's 2008 decision in Boumediene v. Bush); Tim Reid, Guantanamo Trials in Disarray After Court Ruling, TIMEs (London), June 13, 2008, at 40 (same); Patti Waldmeir, Top U.S. Court at Odds with Bush over His Powers, Fin. TIMES, Mar. 26, 2008, at 9 (reporting United States Supreme Court decision in Medellin v. Texas).

4. See infra Parts II.A., III.C.

5. See, e.g., Gary B. Born, International Commercial arbitration in the United STATES: COMMENTARY \& MATERIALS chs. 4-5 (1994) (covering enforcement of arbitration agreements and arbitral awards); CURTIS A. BRADLEY \& JACK L. GOLDSMITH, Foreign RELATIONS LAW: CASES AND MATERIALS chs. 6-8 (2d ed. 2006) (covering extraterritoriality and domestic effect of international law); JACK H. FRIEDENTHAL ET AL., Civil Procedure ch. 3 (4th ed. 2005) (covering personal jurisdiction and forum non conveniens); MARK WESTON JANIS, INTERNATIONAL LAW ch. 5 (5th ed. 2008) (covering international court judgments); EugENE F. SCOLES ET AL., CONFLICT OF LAWS chs. 2, 24 (4th ed. 2004) (covering international choice of law and foreign judgments).
} 
This Article cuts across doctrinal categories to provide a systematic analysis of the global governance functions of domestic courts. ${ }^{6}$ By doing so, it builds on existing legal and political science scholarship on domestic judicial governance and judicialization. This scholarship has made a rich contribution to our understanding of the role of domestic courts in domestic governance. ' So far, however,

6. For a preliminary attempt at such an analysis, see Christopher A. Whytock, Domestic Courts and Global Governance: The Politics of Private International Law ch. 1 (2007) (unpublished Ph.D. dissertation, Duke University), available at http://dukespace. lib.duke.edu/dspace/handle/10161/452 [hereinafter Whytock, Domestic Courts] (developing concept of "transnational judicial governance" to describe the role of domestic courts in global governance). Several other bodies of prior scholarship are also relevant. For example, prior scholarship has analyzed the global governance implications of specific types of domestic court decision making. See, e.g., Tonya L. Putnam, Courts Without Borders: Domestic Sources of U.S. Extraterritoriality in the Regulatory Sphere, 63 INT'L ORG. 459 (2009) (analyzing extraterritorial application of domestic law); Christopher A. Whytock, Myth of Mess? International Choice of Law in Action, 84 N.Y.U. L. REV. 719 (2009) [hereinafter Whytock, Myth of Mess] (analyzing international choice of law decision making). Prior scholarship has also discussed the governance implications of specific types of litigation in domestic courts. See, e.g., Hannah L. Buxbaum, Transnational Regulatory Litigation, 46 VA. J. INT'L L. 315 (2006) (analyzing transnational regulatory litigation); ShiLing Hsu \& Austen L. Parrish, Litigating Canada-U.S. Transboundary Harm: International Environmental Lawmaking and the Threat of Extraterritorial Reciprocity, 48 VA. J. INT'L L. 1 (2007) (analyzing transnational environmental litigation); Harold Hongju Koh, Transnational Public Law Litigation, 100 YALE L.J. 2347 (1991) (analyzing transnational public law litigation); Robert Wai, Transnational Private Litigation and Transnational Governance, in CRITICiZing Global Governance 243 (Markus Lederer \& Philipp S. Müller eds., 2005) (analyzing transnational private litigation). Additionally, there is existing research on transgovernmental networks of judges. See, e.g., ANNE-MARiE Slaughter, A New World ORDER ch. 2 (2004) (documenting transgovernmental networks of judges). Recent scholarship also draws attention to the role of domestic courts in promoting the democratic accountability of states and international organizations in global governance. See Eyal Benvenisti \& George W. Downs, Toward Global Checks and Balances, 20 CONST. POL. ECON. 366, 385 (2009) ("[D]omestic courts are becoming crucial players whose input indirectly improves the accountability and hence legitimacy of intergovernmental action, and thereby contribute to the evolution of more democratic forms of international cooperation.'). Lastly, prior scholarship has focused on the contributions of domestic courts to the international legal order. See, e.g., Benedetto Conforti, International LAW AND the Role of Domestic Legal Systems (René Provost trans., 1993) (analyzing contributions of domestic courts to international legal order); RICHARD A. FALK, THE ROLE OF DOMESTIC COURTS IN THE INTERNATIONAL LEgAL ORDER (1964) (same); Friedrich Kratochwil, The Role of Domestic Courts as Agencies of the International Legal Order, in InTERNATIONAL LAW: A CONTEMPORARY PERSPECTIVE 236 (Richard Falk, Friedrich Kratochwil \& Saul H. Mendlovitz eds., 1985) (same); Jenny S. Martinez, Towards an International Judicial System, 56 STAN. L. REV. 429 (2003) (same).

7. Examples of scholarship on the role of domestic courts in domestic governance include Ran Hirschl, TOWARDS JuRistocracy: THE ORIGINS AND CONSEQuenCES OF THE New Constitutionalism (2004); MARTIN Shapiro, Courts: A COMPARATIVE AND Political Analysis (1981); Martin Shapiro \& Alec Stone Sweet, On Law, Politics, And Judicialization (2002); The Global Expansion of Judicial Power (C. Neal Tate \& Torbjörn Vallinder eds., 1995); Robert A. Dahl, Decision-Making in a Democracy: The 
scholars have devoted relatively little attention to "transnational judicial governance"- that is, the role of domestic courts in global governance. ${ }^{8}$ This Article seeks to make a contribution by demonstrating the importance of this neglected dimension of judicial governance and by providing a framework for understanding it. ${ }^{9}$

Part II of this Article begins by presenting a functional account of domestic courts as global governors. ${ }^{10}$ At first it may seem counterintuitive that domestic legal institutions play an important role in global governance. ${ }^{11}$ But as Part II demonstrates, domestic courts provide support for transnational activity by performing two global governance functions: they allocate global governance authority (a jurisdictional function), and they determine rights and obligations of

Supreme Court as a National Policy-Maker, 6 J. PuB. L. 279 (1957). In addition, legal scholars and political scientists are increasingly studying the role of international courts in global governance. See, e.g., Karen J. Alter, Establishing THE Supremacy OF European LAW: THE MAKING OF AN INTERNATIONAL RULE OF LAW IN EuROPE 219-20 (2001) (analyzing role of European Court of Justice in European governance); COURTS CROSSING BORDERS: BluRRING THE LiNES OF SovEREIGNTY (Mary L. Volcansek \& John F. Stack, Jr., eds., 2005) (studying generally the role of international courts in world politics); Wayne Sandholtz \& Alec Stone Sweet, Law, Politics, and International Governance, in THE POLITICS OF INTERNATIONAL LAW 238 (Christian Reus-Smit ed., 2004) (analyzing global governance implications of World Trade Organization and European Court of Justice).

8. See Whytock, Domestic Courts, supra note 6, at 7 (defining "transnational judicial governance as the governance of transnational activity by domestic courts" (internal quotation marks omitted)).

9. For examples of scholarship focused on specific instances of what this Article calls transnational judicial governance, see the works cited supra note 6. Although the Article primarily uses examples from the U.S. federal courts (and, to a lesser extent, the European legal system), the goal is to provide a conceptual framework for understanding the global impact of domestic courts in general.

10. See Deborah Avant, Martha Finnemore \& Susan K. Snell, Who Governs the Globe? 1 (2008) (manuscript at 1, on file with author) ("[G]lobal governors are actors who exercise power across borders for purposes of affecting policy .... Governors thus: create issues, set agendas, establish and implement rules or programs, and evaluate and/or adjudicate outcomes.").

11. "Global governance" refers to the process of guiding and restraining transnational activity. See Robert O. Keohane, Power and Governance in a Partially Globalized WORLD 202, 245-46 (2002) (defining governance as "the processes and institutions, both formal and informal, that guide and restrain ... collective activit[y]"). This Article uses the adjective "transnational" to refer to activity (such as litigating, disputing, bargaining, contracting) having connections to more than one state and to actors engaged in such activity. The connections may be territorial when the activity or its effects touch the territory of more than one state, or they may be based on legal relationships between a state and the actors engaged in or affected by that activity, such as nationality. Whereas the term "international" refers to activity and institutions involving only states, the more general term "transnational" refers not only to international activity, but also to activity involving nonstate actors. See Joseph S. Nye, Jr. \& Robert O. Keohane, Transnational Relations and World Politics: An Introduction, 25 INT'L ORG. 329, 329-32 (1971) (explaining meaning of "international" and "transnational"). 
transnational actors (a substantive function). These functions correspond to two fundamental questions of global governance. Jurisdictionally, the question is: Who governs? For example, should transnational activity be governed by U.S. law or the law of a foreign state with connections to that activity? ${ }^{12}$ Should a U.S. court or a foreign court adjudicate disputes arising from that activity? Alternatively, is there an international or private institution that should govern the activity? Domestic courts help answer the "who governs" question by allocating governance authority among states, between domestic and international institutions, and between public and private institutions. Substantively, the question is: Who gets what? For example, who is entitled to what benefits under disputed transnational contracts? Who is obligated to bear the costs of negative externalities resulting from transnational activity, ranging from personal injuries to cross-border environmental harm? Domestic courts help answer the "who gets what" question by determining rights and obligations of transnational actors. ${ }^{13}$

Part III shows that the global governance functions of domestic courts matter not only because of their direct impact on litigants, but also - and perhaps even more importantly - because of their influence beyond borders and beyond the parties to particular lawsuits. Domestic court decisions affect the behavior of transnational actors, including strategic behavior such as transnational bargaining and forum shopping. These decisions can either increase or reduce global economic welfare. They also can either foster or hinder the effectiveness of international institutions, such as international law and international courts, and private institutions, such as transnational contracting and transnational arbitration. These broader effects are part of what this Article refers to as the "transnational shadow of the law." ${ }^{\prime 4}$ These effects suggest that domestic courts play an important

12. This Article uses the term "state" in the international legal sense, that is, to refer to a "country" such as the United States or Kenya rather than a U.S. state such as California or Utah. See Restatement (ThiRD) Foreign Relations LaW of the United States $\S 201$ (1987) ("Under international law, a state is an entity that has a defined territory and a permanent population, under the control of its own government, and that engages in, or has the capacity to engage in, formal relations with other such entities."); BARRY E. CARTER, Phillip R. TRimble \& Allen S. Weiner, InTERnATIONAL LAW 444 (5th ed. 2007) (“A 'state' in international law is what we often refer to as a nation or country (such as the United States of America or Japan) and is not one of the 50 U.S. states (such as California).").

13. By answering the "who governs" question, domestic courts determine who should answer the "who gets what" question.

14. See Robert H. Mnookin \& Lewis Kornhauser, Bargaining in the Shadow of the Law: The Case of Divorce, 88 YALE L.J. 950, 951, 972-73 (1979) (describing the "shadow of 
role in global governance. At the very least, the effectiveness of alternative governance arrangements like international institutions and transnational private institutions depends significantly on the support of domestic courts. Transnational judicial governance, which is so far only on the margins of global governance scholarship, therefore deserves close attention along with international forms of global governance (such as international law and international courts) and private forms of global governance (such as transnational arbitration).

Part IV proposes a method for descriptive, positive-theoretical, and normative analysis of the contributions of domestic courts to global governance. The method-which this Article calls "governance-oriented analysis"- - has two basic characteristics. First, it combines analysis of transnational legal doctrine with analysis of transnational law in action: that is, it focuses on how domestic courts actually apply legal doctrine to allocate governance authority and determine the rights and obligations of transnational actors. ${ }^{15}$ Second, it moves beyond traditional litigant-oriented perspectives in order to improve understanding of the transnational shadow of the law: that is, it focuses on the border-crossing impact of domestic court decisions on the behavior of transnational actors, on global economic welfare, and on the effectiveness of international and private governance institutions. By using this method, scholars and policy makers can begin developing the empirical foundations needed for the intensifying debate about the appropriate role of domestic courts in addressing global challenges. ${ }^{16}$

the law" concept in domestic context); see also Martin Shapiro, Courts, in 5 HANDBOOK OF Political Science: Governmental Institutions and Processes 321, 329 (Fred I. Greenstein \& Nelson W. Polsby eds., 1975) ("[L]egalized bargaining under the shadow supervision of an available court ... is not purely mediatory, because the bargain struck will depend in part on the 'legal' strength of the parties, that is, predictions of how each would fare in court."); Whytock, Domestic Courts, supra note 6, at 24 (describing the "transnational shadow of domestic law" (internal quotation marks omitted)).

15. See Philip C. Jessup, Transnational LaW 2 (1956) (defining "transnational law" as including law "which regulates actions or events that transcend national frontiers" (internal quotation marks omitted)); see also Roscoe Pound, Law in Books and Law in Action, 44 AM. L. REV. 12, 15 (1910) (distinguishing between "law in books" and "law in action").

16. Compare Buxbaum, supra note 6, at 316 (arguing that under proper circumstances, domestic courts can help "implement[] effective regulatory strategies for global markets"), and Wai, supra note 6, at 244 (arguing that domestic courts could be "part of a plural regime for the governance of transnational economic activity"), with Curtis A. Bradley, The Costs of International Human Rights Litigation, 2 CHI. J. INT'L L. 457, 457-58, 460 (2001) (arguing that international human rights litigation in U.S. courts creates significant costs for U.S. foreign relations, U.S. democracy, and the international system), and Julian Ku \& John Yoo, Beyond Formalism in Foreign Affairs: A Functional Approach to the Alien Tort Statute, 2004 SUP. CT. REV. 153, 181 (2004) (arguing that federal courts suffer 
In highlighting the role of domestic courts, this Article does not intend to downplay the role of other actors in global governance. To the contrary, it emphasizes that a wide variety of institutionsdomestic and international, public and private, formal and informalmake critical contributions to global governance. ${ }^{17}$ Ultimately it is more important to understand the relationships between these different forms of global governance, and which are most appropriate in different circumstances, than to establish which form is dominant.

\section{The Global Governance Functions of DOMESTIC COURTS}

Among the myriad disputes that flow into the domestic courts of the world's states are disputes arising from transnational activity. Judicial workload data shows that transnational litigation constitutes an important part of the docket of the U.S. district courts. ${ }^{18}$ And although the worldwide volume of transnational litigation in domestic courts is difficult to estimate, legal scholars speculate that globalization and the intensifying transnational interactions it entails have caused transnational litigation to grow in recent decades. ${ }^{19}$

Transnational litigation in domestic courts raises legal issues ranging from personal and subject matter jurisdiction to forum non conveniens and international comity, from foreign sovereign immunity and the act of state doctrine to lis pendens stays and antisuit injunctions, from prescriptive jurisdiction and choice of law to the enforceability of forum selection and arbitration agreements, and from the recognition and enforcement of foreign judgments and arbitral

"significant disadvantages" compared to other institutions in the development and enforcement of customary international law).

17. See infra Part III.C.

18. This data includes the number of lawsuits over which U.S. district courts have alienage jurisdiction - that is, jurisdiction on the ground that the dispute is between "citizens of a [U.S.] State and citizens or subjects of a foreign state." 28 U.S.C. $\S 1332$ (2006). Analyzing data collected by the Administrative Office of the United States Courts, Kevin Clermont and Theodore Eisenberg find that since 1986, well over 120,000 alienage cases terminated in the U.S. federal district courts, and that in 2005 alone 1,976 such cases terminated. Kevin M. Clermont \& Theodore Eisenberg, Xenophilia or Xenophobia in U.S. Courts? Before and After 9/11, 4 J. EMPIRICAL Legal Stud. 441, 462 (2007). This data likely underestimates the total volume of transnational litigation in the United States. Christopher A. Whytock, Litigation, Arbitration, and the Transnational Shadow of the Law, 18 DUKE J. COMP. \& INT’L L. 449, 457-69 (2008).

19. See, e.g., Paul R. Dubinsky, Is International Litigation a Field? Two Views of the Border, 101 AM. SOC'Y INT'L L. PROC. 365, 366 (2007) (describing growth of transnational litigation); Martinez, supra note 6, at 441-42 (same). 
awards to the domestic effect of treaties. ${ }^{20}$ Legal scholarship organizes these issues into diverse doctrinal categories such as civil procedure, conflict of laws, arbitration law, international law, and foreign relations law. ${ }^{21}$

But behind this doctrinal complexity lie two basic global governance functions that domestic courts perform when they make decisions in transnational litigation: they allocate governance authority among states, between domestic and international institutions, and between public and private institutions (a jurisdictional function); and they determine rights and obligations of transnational actors (a substantive function). ${ }^{22}$ These functions correspond to two fundamental questions of global governance: Who governs? And who gets what? In this sense, domestic courts are global governors. ${ }^{23}$

This Part explains the global governance functions of domestic courts and demonstrates the support that domestic courts can provide for transnational activity. The result is a simple functional map of transnational litigation that puts into relief the contributions of domestic courts to global governance, contributions that a purely doctrinal perspective obscures.

\section{A. Who Governs? Judicial Allocation of Global Governance Authority}

The first fundamental question of global governance is: Who governs? $?^{24}$ That is, who has the authority to govern particular

20. Gary B. Born \& Peter B. Rutledge, International Civil Litigation in UNITED STATES COURTS (4th ed. 2007).

21. See sources cited supra note 5 (giving examples of doctrinal categorization). Some of the topics covered by transnational litigation, civil procedure, foreign relations law, conflict of laws, and international law are sometimes brought together under the heading of "transnational law." See, e.g., JESSUP, supra note 15 (defining "transnational law" as including law "which regulates actions or events that transcend national frontiers" (internal quotation marks omitted)).

22. Although the substantive and jurisdictional functions are different conceptually, jurisdictional issues can, of course, affect substantive litigation outcomes.

23. See AvANT ET AL., supra note 10 (manuscript at 1) (defining concept of "global governors").

24. Miles Kahler, Global Governance Redefined 3, 6 (Oct. 2004) (unpublished manuscript), available at http://irpshome.ucsd.edu/assets/014/6742.pdf; see also DANIEL W. Drezner, All Politics Is Global: ExPlaining InTERnational Regulatory Regimes 6 (2007) (explaining the importance of "who makes [the rules]" in transnational regulation); Mark A. Pollack \& Gregory C. Shaffer, Who Governs?, in TRANSATLANTIC GOVERNANCE IN THE Global ECONOMY 287 (Mark A. Pollack \& Gregory C. Shaffer eds., 2001) (asking "who governs," and distinguishing governance by international, transgovernmental, and private entities). The "who governs" question was first prominently asked in the context of domestic 
transnational activity? Domestic courts help answer the "who governs" question by allocating governance authority. This is the jurisdictional global governance function of domestic courts.

In the language of international law, three types of governance authority are at stake: adjudicative authority, the authority to interpret and apply rules; prescriptive authority, the authority to prescribe rules; and enforcement authority, the authority to enforce rules. ${ }^{25}$ But as this Part explains, whereas international law traditionally contemplates only states as capable of possessing these types of authority, ${ }^{26}$ domestic courts help allocate governance authority not only among states, but also between domestic and international institutions and between public and private institutions.

Thus, domestic courts answer three variants of the fundamental "who governs" question: Who adjudicates? Who prescribes? And who enforces? And they do so along three dimensions: domesticforeign, domestic-international, and public-private. This Subpart illustrates how domestic courts help answer these different forms of the "who governs" question, thus performing an important jurisdictional function in global governance. ${ }^{27}$

\section{Allocation of Governance Authority Among States}

First, domestic courts help allocate governance authority among states. To consider this dimension of judicial allocation of governance authority, imagine a hypothetical dispute between AmeriCo, a U.S. corporation, and RuriCo, a Ruritanian corporation, arising out of transnational activity with connections to both the United States and

politics by Robert Dahl. Robert A. DAhl, Who Governs? DemOCRACY ANd POWER IN AN AMERICAN CITY (1961).

25. See Restatement (Third) of Foreign Relations LaW of the United States $\S 401$ (1987). These three types of governance authority correspond approximately to the three traditional questions of conflict of laws: "Where can the parties resolve a dispute ...?" What law applies? What is the effect of a resulting judgment? RUSSELL J. WEINTRAUB, COMMENTARY ON THE CONFLICT OF LAWS 1 (5th ed. 2006). For ease of exposition, I discuss the three types of governance authority in the order in which they are typically addressed by judges and litigants (adjudicative, prescriptive, enforcement) rather than the order in which they are traditionally discussed in international law (prescriptive, adjudicative, enforcement).

26. See Restatement (ThiRd) of Foreign Relations LaW of the United States $\S 401$ introductory note (referring to the authority of a state to prescribe, adjudicate, and enforce).

27. Cf. William S. Dodge, Breaking the Public Law Taboo, 43 HaRv. InT'L L.J. 161, 162 (2002) (referring to the "structural rules of transnational law," defined as "rules concerning prescriptive jurisdiction, judicial jurisdiction, and the enforcement of judgments that together determine the effectiveness of transnational regulation" (internal quotation marks omitted)). 


\author{
Ruritania. Suppose further that AmeriCo sues RuriCo in a U.S. federal \\ court.
}

\title{
a. Adjudicative Authority
}

A variety of decisions by the U.S. court can influence whether the U.S. court or a Ruritanian court will assert adjudicative authority over the dispute. Some of these decisions are unilateral in the sense that they determine whether the U.S. court has authority or not. Such decisions are made without regard to whether a Ruritanian court may also have authority and, if so, whether assertion of that authority by Ruritania would be more appropriate than the assertion of U.S. authority. ${ }^{28}$ For example, by deciding that it has personal jurisdiction and subject matter jurisdiction, a U.S. court establishes the grounds upon which it can assert adjudicative authority. ${ }^{29}$ By deciding that it lacks either type of jurisdiction, the U.S. court declines to assert adjudicative authority, and the case will be dismissed. ${ }^{30}$ Similarly, a U.S. court may decline to exercise adjudicative authority over transnational activity based on theories of foreign sovereign immunity ${ }^{31}$ or the political question doctrine, ${ }^{32}$ again without consideration of

28. See Ralf Michaels, Two Paradigms of Jurisdiction, 27 MicH. J. INT'L L. 1003, 1031-32 (2006) (defining unilateral theories of jurisdiction as those that "determine whether the courts of a state have jurisdiction or not, regardless of whether the courts of other states also have jurisdiction"); see also id. at 1027 (noting that unilateral decisions are made "in disregard of potential claims of other legal systems").

29. FED. R. CIV. P. 12(b)(2) provides for motions to dismiss for lack of jurisdiction over the defendant (that is, for lack of personal jurisdiction), and FED. R. CIV. P. 12(b)(1) provides for motions to dismiss for lack of subject matter jurisdiction. A defendant may also seek to transfer the case to another forum within the United States under 28 U.S.C. $\S \S 1404$, 1406 (2006).

30. The Supreme Court has implied that courts should pay some attention to multilateral concerns when determining whether to assert personal jurisdiction. See, e.g., World-Wide Volkswagen Corp. v. Woodson, 444 U.S. 286, 292 (1980) (stating that the reasonableness of asserting personal jurisdiction will depend, among other things, on "the interstate judicial system's interest in obtaining the most efficient resolution of controversies; and the shared interest of the several States in furthering fundamental substantive social policies"). But, as Ralf Michaels argues, "[m]ultilateral effects of allocation of jurisdiction are not prime goals but mere reflective consequences of unilateral considerations. They are subsumed ...." Michaels, supra note 28, at 1033-34. Of course, a decision that a U.S. federal court lacks subject matter jurisdiction does not necessarily preclude subject matter jurisdiction in a U.S. state court. Moreover, a decision that a court in a particular U.S. state lacks personal jurisdiction does not necessarily mean that personal jurisdiction cannot lie in a court in another U.S. state.

31. Under the Foreign Sovereign Immunities Act of 1976, foreign states are immune from suit in U.S. state and federal courts unless the relevant court determines that an exception specified in the Act applies. 28 U.S.C. $§ 1604$.

32. Under the political question doctrine, a court may dismiss a lawsuit if the court determines that it poses a nonjusticiable political question. See Baker v. Carr, 369 U.S. 186, 
whether it would be appropriate for a Ruritanian court to assert its own adjudicative authority. ${ }^{33}$ But unilateral decisions only provide a partial answer to the "who adjudicates" question. If the court decides not to assert adjudicative authority, the question remains: If not the United States, then which state's courts should assert adjudicative authority?

Other U.S. court decisions are multilateral in the sense that they explicitly consider reasons why it may be more appropriate for a foreign state to assert its adjudicative authority. According to the forum non conveniens doctrine, a federal district court may dismiss an action in favor of a foreign court "on the ground that a court abroad is the more appropriate and convenient forum for adjudicating the controversy. ${ }^{\text {"34 }}$ By denying a motion to dismiss on forum non conveniens grounds and keeping the case, the U.S. court asserts domestic adjudicative authority over the underlying transnational activity; by granting the motion and dismissing the case in favor of a Ruritanian court, the U.S. court defers to Ruritanian adjudicative authority. Although a U.S. court cannot force a foreign court to assert adjudicative authority over transnational activity, ${ }^{35}$ these decisions

217 (1962). The Supreme Court set forth criteria for determining nonjusticiability, including whether there is:

a textually demonstrable constitutional commitment of the issue to a coordinate political department; or a lack of judicially discoverable and manageable standards for resolving it; or the impossibility of deciding without an initial policy determination of a kind clearly for nonjudicial discretion; or the impossibility of a court's undertaking independent resolution without expressing lack of the respect due coordinate branches of government; or an unusual need for unquestioning adherence to a political decision already made; or the potentiality of embarrassment from multifarious pronouncements by various departments on one question.

Id. See generally Thomas M. Franck, Political Questions/Judicial Answers: Does the RULE OF LAW APPLY TO FOREIGN AFFAIRS? (1992) (discussing political question doctrine).

33. Additional unilateral doctrines used to dismiss transnational litigation may include standing, ripeness, and mootness. See, e.g., Harold Hongju Koh, Why the President (Almost) Always Wins in Foreign Affairs: Lessons of the Iran-Contra Affair, 97 YALE L.J. 1255, 1313-14 (1988) (discussing the use of standing, ripeness, and mootness doctrines to dismiss foreign affairs cases); Patrick M. McFadden, Provincialism in United States Courts, 81 CoRNELl L. REV. 4, 60-61 (1995) (discussing the use of personal jurisdiction and standing as doctrines used to dismiss transnational litigation).

34. Sinochem Int'l Co. v. Malay. Int'l Shipping Corp., 549 U.S. 422 (2007).

35. Michaels, supra note 28 , at 1045 . Indeed, one study suggests that after U.S. courts dismiss cases on forum non conveniens grounds, they typically are not refiled in the proposed alternative forum. David W. Robertson, Forum Non Conveniens in America and England: "A Rather Fantastic Fiction,"103 LaW Q. REV. 398, 417-21 (1987). Although this is obviously important from a litigant-oriented perspective, this does not change the fact that these decisions involve choices about adjudicative authority. As Michaels puts it, "the fact that courts do not perform their multilateral tasks well has no impact on the fact that this task is multilateral." Michaels, supra note 28 at 1037 n.151. 


\author{
either implicitly or explicitly involve deference to foreign adjudicative \\ authority. ${ }^{36}$
}

Similarly, judicial enforcement or nonenforcement of choice of forum agreements can help determine whether a U.S. or foreign court will adjudicate a dispute. ${ }^{37}$ When a U.S. court enforces an agreement to litigate in a foreign court, it defers to foreign adjudicative authority. By declining to enforce such an agreement and adjudicating the dispute itself, or by enforcing an agreement to litigate in a U.S. court, it asserts domestic adjudicative authority. ${ }^{38}$

Other decisions - including decisions to dismiss transnational litigation based on international comity ${ }^{39}$ or the act of state doctrine ${ }^{40}$ and decisions to stay litigation on lis alibi pendens grounds when

36. See Am. Dredging Co. v. Miller, 510 U.S. 443, 453 (1994) (describing forum non conveniens as a doctrine for "determining which among various competent courts will decide the case"); Gulf Oil Corp. v. Gilbert, 330 U.S. 501, 507 (1947) (noting that "the doctrine furnishes criteria for choice between" a domestic forum and a foreign forum); JANIS, supra note 5 , at 343 ("[C]ourts have fashioned forum non conveniens as a means by which to defer to foreign states and foreign courts."); Allan R. Stein, Forum Non Conveniens and the Redundancy of Court-Access Doctrine, 133 U. PA. L. REV. 781, 786 (1985) (describing forum non conveniens "as a means of allocating political authority"). In fact, U.S. courts often make forum non conveniens dismissals subject to the condition that the defendant submit to personal jurisdiction in the foreign forum. See generally John Bies, Comment, Conditioning Forum Non Conveniens, 67 U. CHI. L. REv. 489-90 (2000).

37. On choice of forum agreements, see BORN \& RUTLEDGE, supra note 20, ch. 5.

38. Alternatively, decisions whether to enforce choice of forum agreements can be understood in terms of deference (in the case of enforcement) or lack of deference (in the case of nonenforcement) to private authority - namely, the authority of private parties to select their forum by contract.

39. Comity is "the recognition which one nation allows within its territory to the legislative, executive or judicial acts of another nation, having due regard both to international duty and convenience, and to the rights of its own citizens or of other persons who are under the protection of its laws." Hilton v. Guyot, 159 U.S. 113, 163-164 (1895); see, e.g., UngaroBenages v. Dresdner Bank AG, 379 F.3d 1227 (11th Cir. 2004) (dismissing action based on international comity doctrine after considering both U.S. and foreign interests, and describing comity as an abstention doctrine allowing a federal court that has jurisdiction nevertheless to defer to the judgment of a foreign forum).

40. According to the act of state doctrine, "[e]very sovereign State is bound to respect the independence of every other sovereign State, and the courts of one country will not sit in judgment on the acts of the government of another done within its own territory." Underhill v. Hernandez, 168 U.S. 250, 252 (1897). Whether the act of state doctrine is better characterized as unilateral or multilateral is unclear. While the doctrine's roots are in international law and comity, it alternatively has been characterized as a separation of powers doctrine and a choice of law doctrine. BORN \& RUTLEDGE, supra note 20, at 751-55. Insofar as it is based on comity or choice of law principles, it is multilateral. As Janis argues, "Despite their doctrinal differences, the act of state doctrine and the rules of foreign sovereign immunity are functionally similar insofar as both defer to foreign sovereigns ...." JANIS, supra note 5 , at 365 . 
parallel litigation is pending in a foreign court ${ }^{41}$ —are also multilateral in the sense that they are decisions not only to decline assertion of U.S. adjudicative authority, but also to defer to foreign adjudicative authority. Decisions to issue antisuit injunctions can also be understood as multilateral, although they are assertions of U.S. adjudicative authority. ${ }^{42}$

\section{b. Prescriptive Authority}

The U.S. court may also make unilateral or multilateral decisions affecting the allocation of prescriptive authority, thus responding to the "who prescribes" variant of the fundamental "who governs" question. Continuing the example above: Should U.S. law or Ruritanian law be applied to govern the transnational activity giving rise to the dispute between AmeriCo and RuriCo? Unilaterally, the U.S. court might simply decide whether the United States has prescriptive authority or not. ${ }^{43}$ The most prominent examples of prescriptive jurisdiction decisions in the U.S. federal courts are decisions about whether U.S. federal statutes and regulations should be applied extraterritorially. ${ }^{44}$ These decisions help allocate prescriptive authority among states because they determine whether or not the law of one state-the United States - will be applied to transnational activity. But they leave the second half of the "who prescribes" question unanswered: If not the United States, then which state should prescribe the rules to govern particular transnational activity $?^{45}$

41. Lis alibi pendens is a doctrine that "permits a U.S. court to stay an action before it in deference to pending foreign litigation." BORN \& RUTLEDGE, supra note 20, at 522. The extent to which lis pendens decisions are based on multilateral considerations may vary by district. Id. at 524-25.

42. Antisuit injunctions are injunctions that "enjoin a litigant from commencing or continuing litigation in a foreign forum." Id. at 522. The considerations underlying antisuit injunctions are not necessarily multilateral. Id. at 540-43. Nevertheless, the occasion to issue them only arises when the U.S. court has notice of a pending or threatened parallel suit in a foreign court, making antisuit injunction decisions choices between domestic and foreign adjudicative authority. I therefore treat them as multilateral.

43. Id. at 613. For an important empirical analysis of U.S. federal court decisions to apply (or not apply) U.S. law extraterritorially, see Putnam, supra note 6.

44. See generally Austen L. Parrish, Reclaiming International Law from Extraterritoriality, 93 MinN. L. REV. 815, 820 (2009).

45. In fact, when U.S. courts decide that U.S. federal law does not apply extraterritorially, they typically proceed to dismiss the lawsuit because, given the inapplicability of the U.S. law, either the plaintiff no longer has a legal basis for its claim or the court no longer has the authority to adjudicate. BORN \& RUTLEDGE supra note 20, at 674. See generally ANDREAS F. LOWENFELD, INTERNATIONAL LITIGATION AND THE QUEST FOR REASONABLENESS 16-17 (1996). 
Multilaterally, the U.S. court can allocate prescriptive authority by making international choice of law decisions - that is, by deciding whether U.S. law or Ruritanian law should apply to activity that has connections to both states. ${ }^{46}$ International choice of law analysis is closely related to prescriptive jurisdiction analysis: unless a state has prescriptive jurisdiction, its law is not eligible for selection as applicable law. ${ }^{47} \quad$ But whereas prescriptive jurisdiction analysis is unilateral in the sense that it determines whether or not a given state has authority, international choice of law analysis is multilateral in the sense that it determines which state's law should apply. By deciding that U.S. law should apply, the U.S. court asserts U.S. prescriptive authority, and by deciding that Ruritanian law should apply, the court defers to foreign prescriptive authority. ${ }^{48}$

\section{c. Enforcement Authority}

Domestic courts also make decisions that affect the allocation of enforcement authority among states, thus helping to answer the "who enforces" variant of the "who governs" question. For example, U.S. courts have determined whether extraterritorial seizures of vessels by the United States, ${ }^{49}$ extraterritorial service of subpoenas by U.S. regulatory agencies, ${ }^{50}$ and injunctions issued by U.S. courts with

46. See Whytock, Domestic Courts, supra note 6, at 14, 154. Although international choice of law is a multilateral decision, insofar as it involves a choice between one state's law and another's rather than simply a decision about whether one state's law applies, not all choice of law methods are multilateral. For example, the lex fori method is based on a general presumption that domestic law applies. SCOLES ET AL., supra note 5, at 737-41.

47. BORN \& RUTLEDGE, supra note 20, at 561.

48. As Joel Trachtman argues, "The durable technical legal questions of choice of law and prescriptive jurisdiction resolve into [the same] core normative public policy issue: how should authority be allocated within an interstate or international system?" Joel P. Trachtman, Economic Analysis of Prescriptive Jurisdiction, 42 VA. J. INT'L L. 1, 3 (2001).

49. See, e.g., The Apollon, 22 U.S. 362 (1824). In that case, a French ship allegedly entered the United States, failing to pay tonnage duties required by U.S. law. Id. at 363-65. U.S. authorities later arrested the ship in Spanish territorial waters. Id. The Supreme Court held that the arrest was unjustified, considering Spain's exclusive jurisdiction and noting that "[i]t would be monstrous to suppose that our revenue officers were authorized to enter into foreign ports and territories, for the purpose of seizing vessels which had offended against our laws." Id. at 371-72.

50. See, e.g., Fed. Trade Comm'n v. Compagnie de Saint-Gobain-Pont-A-Mousson, 636 F.2d 1300 (D.C. Cir. 1980). In that case, the U.S. Federal Trade Commission served a subpoena on a French company by registered mail at its headquarters in Paris. Id. at 1305. The French government filed a protest with the U.S. Department of State, arguing that this method of service violated French national sovereignty. Id. at 1306. The U.S. court held that service of the subpoena exceeded U.S. enforcement authority, in violation of international law. Id. at 1318. In reaching its conclusion, the court explained: 
purported extraterritorial effects ${ }^{51}$ exceed U.S. enforcement authority, taking into account multilateral considerations.

Related to but distinct from enforcement authority decisions are U.S. court decisions regarding the enforcement of foreign judgments. These decisions also affect the allocation of governance authority among states, but not always by allocating enforcement authority. Modifying the example above, imagine that RuriCo initiates litigation by suing AmeriCo in a Ruritanian court. The Ruritanian court enters a judgment against AmeriCo, but because AmeriCo refuses to pay and has no assets within Ruritanian territory, RuriCo cannot enforce the judgment there. RuriCo then asks a U.S. court to order enforcement of the Ruritanian court's judgment against AmeriCo's assets in the United States. Should the U.S. court do so?

Superficially, the U.S. court's decision whether to order enforcement of the Ruritanian judgment is unilateral: it is a decision whether to assert U.S. enforcement authority, not a choice between U.S. and Ruritanian enforcement authority. More fundamentally, it is multilateral: the decision presupposes a foreign state's prior assertion of governance authority, and determines whether that assertion of authority will be given domestic effect, an effect it would not otherwise have. ${ }^{52}$ Thus, a U.S. court decision to enforce the Ruritanian

When an American regulatory agency directly serves its compulsory process upon a citizen of a foreign country, the act of service itself constitutes an exercise of American sovereign power within the area of the foreign country's territorial sovereignty. Though some techniques of service may prove less obnoxious than others to foreign sensibilities, our recognition of those sensibilities must affect our willingness to infer congressional authorization for a particular mode of service from an otherwise silent statute. In the face of the foreign country's direct protest to the mode of service employed here, and in the absence of clear congressional intent at the time this subpoena was served to authorize that manner of exercise of American sovereign power, we decline to infer the necessary statutory authority for the FTC's chosen mode of subpoena service.

Id. at 1304 .

51. See, e.g., Republic of Philippines v. Westinghouse Elec. Corp., 43 F.3d 65, 78 (3d Cir. 1994) (vacating district court injunction on international comity grounds because it "purport[ed] to place the court in the position of supervising the law enforcement activities of a foreign sovereign nation against its own citizens on its own soil"); see also Younis Bros. \& Co. v. CIGNA Worldwide Ins. Co., 167 F. Supp. 2d 743, 745 (E.D. Pa. 2001) (noting that pursuant to U.S. enforcement authority, "numerous courts have recognized a district court's power to issue an anti-suit injunction that enjoins litigants over which it has in personam jurisdiction from pursuing duplicative litigation in a foreign forum").

52. See BORN \& RUTLEDGE, supra note 20, at 1009-10 ("[M] ost courts will enforce their own money judgments only against assets within their territorial jurisdiction .... As a general rule, therefore, a judgment will operate in foreign states only if the courts of those states are willing to provide assistance by recognizing or enforcing the judgment ....”). 
judgment implies an affirmation by the U.S. court that it was appropriate under the circumstances for Ruritania to assert its authority to adjudicate the dispute. ${ }^{53}$ In this sense, a domestic court's decision to enforce a foreign judgment can be understood as a form of deference to foreign authority even though it involves a subsidiary assertion of domestic enforcement authority.

Conversely, a refusal to enforce a foreign judgment typically is based on a determination by the U.S. court that the foreign state's court did not have proper jurisdiction over the dispute, that the defendant did not enjoy certain minimum standards of fairness in the foreign court, that enforcement of the foreign judgment would violate U.S. public policy, or that the foreign court's judgment is in some other way defective. $^{54}$ In other words, by refusing to enforce, the U.S. court substitutes its own judgment regarding the proper dispute resolution process or outcome for that of the Ruritanian court. In this sense, a decision not to enforce a foreign judgment can be understood as an assertion of domestic governance authority. ${ }^{55}$

\section{Allocation of Governance Authority Between Domestic and International Institutions}

Domestic courts also contribute to the allocation of governance authority between domestic and international institutions. For example, domestic courts must sometimes respond to the domesticinternational dimension of the "who adjudicates" variant of the "who governs" question: When both a national court and an international court appear to have jurisdiction over a particular dispute, how should

Enforcement decisions are sometimes explicitly multilateral when they are based on considerations of reciprocity. Id. at 1014.

53. This affirmation may be explicit when a judgment debtor argues against enforcement of a foreign judgment by raising the issue of whether the foreign state appropriately exercised its adjudicative authority, and the domestic court rejects the argument and proceeds to enforce the judgment.

54. BORN \& RUTLEDGE, supra note 20, at 1013-15.

55. Born and Rutledge explain:

"Recognition" and "enforcement" of foreign judgments are related but distinct concepts. The recognition of a foreign judgment occurs when a U.S. court relies upon a judicial ruling to preclude litigation of a claim, or issue, on the ground that it has been previously litigated abroad .... In contrast, the enforcement of a foreign judgment occurs when a court uses its coercive powers to compel a defendant . . . to satisfy a judgment rendered abroad.

Id. at 1010. Thus, both decisions to recognize and decisions to enforce foreign judgments can be understood as forms of deference to foreign authority. 
adjudicative authority be allocated between them $?^{56}$ U.S. courts have, for example, applied the forum non conveniens doctrine to choose between assertion of domestic adjudicative authority and deference to the adjudicative authority of an international tribunal. ${ }^{57}$

Moreover, although often overlooked in conflict-of-laws scholarship, ${ }^{58}$ international choice of law problems may involve not only domestic-foreign law conflicts but also domestic-international law conflicts. $^{59}$ Such conflicts raise the domestic-international dimension of the "who prescribes" variant of the fundamental "who governs" question, and domestic courts help answer it in a variety of circumstances.

In the United States, two types of decisions are particularly relevant. First, according to the self-executing treaty doctrine, selfexecuting treaties are treaties that automatically have effect as domestic law under the Supremacy Clause of the United States Constitution, ${ }^{60}$ whereas non-self-executing treaties are not enforceable in domestic courts absent domestic implementing legislation. ${ }^{61}$ In litigation challenging domestic legal rules or governmental action on the ground that they violate a treaty that has not been implemented through legislation, the practical implication is that deference to international

56. See generally Yuval Shany, Regulating JuRisdictional Relations BetweEn NATIONAL AND INTERNATIONAL COURTS 1-2 (2007) (noting instances of overlapping jurisdiction of domestic and international courts); Martinez, supra note 6, at 492, 496-98 (same).

57. See, e.g., Nemariam v. Federal Democratic Republic of Ethiopia, 315 F.3d 390, 395 (D.C. Cir. 2003) (reversing trial court's forum non conveniens dismissal in favor of Ethiopia/Eritrea Claims Commission); In re: Assicurazioni Generali S.P.A. Holocaust Ins. Litig., 228 F. Supp. 2d 348 (S.D.N.Y. 2002) (denying forum non conveniens motion, which sought to dismiss in favor of proceedings before the International Commission on Holocaust Era Insurance Claims). See generally Ryan T. Bergsieker, Comment, International Tribunals and Forum Non Conveniens Analysis, 114 YALE L.J. 443 (2004).

58. For example, neither of the two current leading commentaries on conflict of laws have a section discussing conflicts between domestic law and international law. See Scoles ET AL., supra note 5; WEINTRAUB, supra note 25. However, three leading legal scholars have recently spearheaded an effort to develop a conflict-of-laws approach to conflicts between domestic and international law. See Karen Knop, Ralf Michaels \& Annelise Riles, International Law in Domestic Courts: A Conflict of Laws Approach, 103 AM. SoC'Y of INT'L L. PROC. (2009), available at http://ssrn.com/abstract=1413189.

59. See SeAn D. Murphy, Principles of International Law 147 (2006) ("National courts may be authorized by their states to use international law as a source of law in their decision-making. ... [I]nternational law serves as one source of law among many competing sources, with hierarchies that differ depending on the peculiarities of each nation's constitutional structure.").

60. U.S. CONST. art. VI.

61. See generally JANIS, supra note 5, at 87-89 (discussing self-executing treaty doctrine). 
prescriptive authority depends on judicial characterization of the treaty as self-executing. ${ }^{62}$ Otherwise, the challenged domestic act will prevail over the treaty. ${ }^{63}$ Functionally, then, judicial characterization of a treaty as self-executing or not can help allocate prescriptive authority along the domestic-international dimension. ${ }^{64}$

Second, domestic courts use various interpretive devices to avoid conflicts between domestic and international law in ways that can affect the domestic-international allocation of authority. According to the Charming Betsy canon, "[A]n act of Congress ought never to be construed to violate the law of nations if any other possible construction remains .... ${ }^{96}$ U.S. courts can use this canon of construction to construe a national legal rule to conform to an international legal rule. ${ }^{66}$ As Curtis Bradley argues, "This indirect,

62. See, e.g., Asakura v. City of Seattle, 265 U.S. 332 (1924) (holding city ordinance to be in violation of self-executing treaty). In states where the domestic status of treaties is more clearly delineated by the constitution, or where determinations of that status are vested solely in the legislature, the role of domestic courts in allocating between domestic and international authority may be less important than in the United States. The broader point is that the exact role of domestic courts in allocating governance authority varies crossnationally along with cross-national differences in legal and political systems.

63. See, e.g., Medellin v. Texas, 128 S. Ct. 1346 (2008) (upholding Texas' limitations on habeas applications notwithstanding contrary ruling of International Court of Justice [ICJ] on grounds that the provision of the United Nations Charter obligating members to comply with ICJ judgments is non-self-executing).

64. This function, however, does not affect the status of a treaty as an international obligation of the United States; it only determines whether it "automatically constitute[s] binding federal law enforceable in United States courts." Id. at 1356.

65. The Charming Betsy, 6 U.S. (2 Cranch) 64, 118 (1804). If the conflict involves U.S. federal legislation and cannot be avoided through statutory construction, a U.S. court will ordinarily apply the later-in-time rule to allocate prescriptive authority-a rule that would seem to allow far less discretion than the self-executing treaty doctrine or the Charming Betsy canon. See ReSTATEMENT (ThiRD) OF Foreign RELATIONS LAW OF THE UNITED STATES § 115 (1987). On the Charming Betsy canon, see generally Roger P. Alford, Foreign Relations as a Matter of Interpretation: The Use and Abuse of Charming Betsy, 67 OHIO ST. L.J. 1339 (2006).

66. See, e.g., United States v. Palestine Liberation Org., 695 F. Supp. 1456 (S.D.N.Y. 1988). In that case, the Department of Justice sought an injunction closing the Palestine Liberation Organization's (PLO) observer mission to the United Nations, pursuant to the U.S. Anti-Terrorism Act of 1987 (ATA). The ATA provides:

It shall be unlawful, if the purpose be to further the interests of the Palestine Liberation Organization ... notwithstanding any provision of law to the contrary, to establish or maintain an office, headquarters, premises, or other facilities or establishments within the jurisdiction of the United States at the behest or direction of, or with funds provided by the Palestine Liberation Organization .... .

22 U.S.C.A. § 5202(3) (West 2004). But the presence of the PLO's observer mission in the United States was authorized by the Agreement Between the United States and the United Nations Regarding the Headquarters of the United Nations (Headquarters Agreement). Palestine Liberation Org., 695 F. Supp. at 1458-59. Applying the Charming Betsy doctrine, 
'phantom' use of international law can, in some cases, have the same effect as direct incorporation of international law." ${ }^{97}$ Such conflicts can also be avoided by construing an international legal rule to be consistent with domestic law. ${ }^{68}$ In both cases, a court uses construction to avoid a conflict between domestic and international authority. But in the former, the court effectively defers to international prescriptive authority, while in the latter, the court prioritizes domestic prescriptive authority. Even in the absence of explicit conflict, domestic courts sometimes use international treaties - including non-self-executing treaties - in interpreting domestic law, in a process of "interpretive incorporation" of international law. ${ }^{69}$ Insofar as it increases the extent to which domestic courts interpret domestic legal rules to conform to international legal rules, the use (or nonuse) of this method influences the allocation of prescriptive authority along the domestic-international dimension.

Beyond the self-executing treaty doctrine and canons of construction, U.S. courts make explicit choices between domestic and international law in litigation under the Alien Tort Statute. ${ }^{70}$ Jurisdictionally, the Alien Tort Statute requires a tort "committed in violation of the law of nations or a treaty of the United States." "71 As the rule of decision, however, U.S. courts sometimes apply domestic law (thus asserting domestic prescriptive authority) and sometimes apply international law (thus deferring to international prescriptive authority). ${ }^{72}$ Within the European legal system, national courts frequently defer to the European Court of Justice's (ECJ) interpretations of EU law through the preliminary reference procedure. $^{73}$ And even outside Europe, some domestic courts treat ECJ

the court interpreted the ATA so as not to require closure of the PLO's mission, thus resolving the conflict with the Headquarters Agreement. Id. at 1465.

67. Curtis A. Bradley, The Charming Betsy Canon and Separation of Powers: Rethinking the Interpretive Role of International Law, 86 GEO. L.J. 479, 483 (1997).

68. See, e.g., United States v. Alvarez-Machain, 504 U.S. 655, 666 (1992) (construing the 1978 U.S.-Mexico Extradition Treaty broadly so as not to bar extraterritorial forcible abduction operation by United States Drug Enforcement Administration).

69. See Melissa A. Waters, Creeping Monism: The Judicial Trend Toward Interpretive Incorporation of Human Rights Treaties, 107 CoLUM. L. REV. 628 (2007).

70. See generally Philip A. Scarborough, Rules of Decision for Issues Arising Under the Alien Tort Statute, 107 ColuM. L. REV. 457, 485-500 (2007) (discussing choice between state law and international law in ATS litigation).

71. 28 U.S.C. $\$ 1350$ (2006).

72. See Wiwa v. Royal Dutch Petroleum Co., 226 F.3d 88, 105 (2d Cir. 2000).

73. SHANY, supra note 56, at 33-34. This procedure is authorized by article 234 of the Treaty Establishing the European Community, which provides that the ECJ has 
and European Court of Human Rights decisions as persuasive legal authority, a milder but nevertheless significant form of deference to international prescriptive authority. ${ }^{74}$

In addition, U.S. court decisions regarding the domestic enforceability of international court judgments are relevant to the domestic-international dimension of the "who governs" question. When a domestic court and an international court adjudicate the same issue but with different outcomes, which decision should prevail? By answering this question, domestic courts make not only unilateral decisions about whether to assert domestic enforcement authority to give an international court judgment domestic effect, but also multilateral decisions about whether to give priority to the domestic or international court's adjudication of the issue.

The Supreme Court's 2008 holding in Medellin v. Texas is a prominent example of such a decision. ${ }^{75}$ The state of Texas convicted Medellin, a Mexican national, of murder and sentenced him to death. ${ }^{76}$ During his initial detention, law enforcement officers failed to notify him of his right under the Vienna Convention on Consular Relations to request the assistance of the Mexican consul. ${ }^{77}$ Medellin raised this point only after his conviction, and the state trial court held that the claim was barred by Texas procedural rules requiring him to have raised it at trial or on direct review. ${ }^{78}$ The International Court of Justice

jurisdiction to give preliminary rulings concerning: (a) the interpretation of this Treaty; (b) the validity and interpretation of acts of the institutions of the Community and of the [European Central Bank]; (c) the interpretation of the statutes of bodies established by an act of the Council, where those statutes so provide. Where such a question is raised before any court or tribunal of a Member State, that court or tribunal may, if it considers that a decision on the question is necessary to enable it to give judgment, request the Court of Justice to give a ruling thereon. Where any such question is raised in a case pending before a court or tribunal of a Member State against whose decisions there is no judicial remedy under national law, that court or tribunal shall bring the matter before the Court of Justice.

Treaty Establishing the European Community, Dec. 24, 2002, 2002 O.J. (C 325) 127.

74. Slaughter, supra note 6, at 79-82; see also Karen Knop, Here and There: International Law in Domestic Courts, 32 INT'L L. \& POL. 501 (2000) (criticizing the emphasis on domestic courts as "enforcers" of international law and focusing instead on the use of international law as persuasive authority in domestic courts).

75. 128 S. Ct. 1346 (2008). But see Torres v. Oklahoma, No. PCD-04-442, 2004 WL 3711623, at *3 (Okla. Crim. App. 2004) (Chapel, J., concurring) (granting postconviction relief based on the ICJ's resolution of the dispute under the Vienna Convention).

76. $128 \mathrm{~S}$. Ct. at 1354.

77. Id:; Vienna Convention on Consular Relations art. 36, Apr. 24, 1963, 21 U.S.T. 77, 596 U.N.T.S. 261.

78. $128 \mathrm{~S}$. Ct. at 1353. 
(ICJ) held that the United States thus violated the Vienna Convention and determined that the United States was obligated "to provide ... review and reconsideration of the convictions and sentences" of Medellin and fifty other Mexican nationals similarly convicted by U.S. states without notification of their Vienna Convention rights. ${ }^{79}$ The state of Texas refused to comply with the ICJ's ruling, notwithstanding a memorandum by the U.S. president stating that the United States would "discharge its international obligations" under the ICJ's decision "by having State courts give effect to the decision." The Supreme Court held that the ICJ's judgment was not directly enforceable as domestic law. ${ }^{81}$ The Supreme Court's decision turned on a variety of legal considerations, ${ }^{82}$ but a practical effect of the decision not to enforce was to prioritize the domestic authority of Texas over the international authority of the ICJ.

If, as some scholars suggest, private litigants are increasingly requesting domestic judicial enforcement of the judgments of international courts, ${ }^{83}$ this domestic-international dimension of judicial allocation of governance authority is likely to be of growing importance. $^{84}$ As one observer remarks:

[W]ith the advent of supranational institutions that legislate, prosecute, and adjudicate, and the concomitant need to manage the relationship between those institutions and parallel institutions at the national level, International Law seems likely to become increasingly preoccupied with managing jurisdictional conflicts and developing rules for remedies and choice of law ... ${ }^{85}$

Until such a body of international law develops, however, domestic courts will have an especially important role to play in addressing these issues. Even if such a body of international law does eventually develop, domestic courts will likely play an important role in interpreting and applying it.

79. Id. at 1355 (internal quotation marks omitted).

80. Id. at 1355-56 (internal quotation marks omitted).

81. Id. at 1357.

82. The court held that the relevant treaties were non-self-executing and that the President could not unilaterally render them domestically enforceable against the state of Texas. Id. at 1357, 1368.

83. See, e.g., Ernest A. Young, Toward a Framework Statute for Supranational Adjudication, 57 EMORY L.J. 93, 93 (2007).

84. See, e.g., SHANY, supra note 56, at 2 (noting that the increase in the number and activity of international courts is increasing the opportunities for jurisdictional conflict between national and international courts, giving rise to a "need to regulate jurisdictional overlaps between national and international courts").

85. Young, supra note 83, at 93-94. 


\section{Allocation of Governance Authority Between Private and Public Institutions}

In addition to the allocation of governance authority among states and between domestic and international institutions, domestic courts help allocate governance authority between state and nonstate actors. Returning to the example above, suppose that prior to their dispute, AmeriCo and RuriCo agreed to submit any transnational disputes between them to binding arbitration by a private arbitral institution such as the International Chamber of Commerce. A dispute arises and, notwithstanding the arbitration agreement, AmeriCo sues RuriCo in a U.S. court based on an ex post assessment that it is likely to fare better in litigation than arbitration. RuriCo then asks the U.S. court to enforce the arbitration agreement against AmeriCo. Although there is a presumption in favor of enforcement of arbitration agreements under U.S. and international law, U.S. courts may decline enforcement on a variety of grounds. ${ }^{86}$ By enforcing the agreement, the U.S. court can allocate adjudicative authority to the arbitral institution, thus deferring to private authority. ${ }^{87} \quad$ By refusing to enforce the agreement and allowing litigation to proceed, the U.S. court can instead assert public adjudicative authority.

Domestic courts may also influence the allocation of prescriptive authority between public and private actors. As Symeon Symeonides explains:

$[\mathrm{P}]$ arties may - through an express choice-of-law clause or through "incorporation" - subject their contract to non-state norms, such as commercial usages, the lex mercatoria, the UNIDROIT Principles, the general principles of law, or, in Europe, the Principles of European [Contract] Law (PECL) ... [provided that] the choice of non-state

86. Under article II of the United Nations Convention on the Recognition and Enforcement of Foreign Arbitral Awards, domestic courts may decline to enforce arbitration agreements if they find them "null and void, inoperative or incapable of being performed." U.N. Convention on the Recognition and Enforcement of Foreign Arbitral Awards art. II, June 10, 1958, 21 U.S.T. 2517, 330 U.N.T.S. 38 (entered into force on Dec. 29, 1970) [hereinafter New York Convention]. Under article V, they may decline to enforce arbitral awards on various grounds, including domestic public policy. Id. art. V. Under the Federal Arbitration Act, "[a] court shall confirm [an arbitral award covered by the New York Convention] unless it finds one of the grounds for refusal or deferral of recognition or enforcement of the award specified in the said Convention." 9 U.S.C. § 207 (2006).

87. This is deference to private authority, both because the arbitrator is a nonstate actor, and because the decision gives effect to a private agreement (the agreement to arbitrate). 
norms may not exceed the limits of party autonomy as defined by the state whose law would otherwise govern the contract. ${ }^{88}$

Thus, if AmeriCo and RuriCo agree that their transnational activity shall be governed by, for example, the PECL rather than the law of a particular state, and AmeriCo sues RuriCo in a U.S. court, then the U.S. court can decide whether to apply the PECL on the one hand or, depending on a traditional choice of law analysis, domestic or foreign law on the other hand. By applying the PECL, the U.S. court would defer to the private authority of AmeriCo and RuriCo to select the rules to govern their transnational activity. ${ }^{89}$ By declining to do so and instead applying state law, the U.S. court would assert public prescriptive authority.

In summary, domestic courts perform a jurisdictional global governance function by helping to allocate three types of governance authority over transnational activity: adjudicative authority, prescriptive authority, and enforcement authority. They do so along three dimensions: among states, between domestic and international institutions, and between public and private institutions. The answers to these variants of the fundamental "who governs" question are rarely obvious. Because transnational activity by definition has connections to more than one state, more than one state may have a basis for legitimately exercising the authority to govern it. With private actors increasingly claiming authority to govern transnational activity traditionally governed by the state, the allocation of governance authority between public and private institutions also poses serious challenges. $^{90}$ And with the spread of international law and international courts, there are equally difficult choices to make about whether they or domestic institutions should govern particular transnational activity. ${ }^{11} \quad$ As a result, the jurisdictional function of domestic courts in global governance is likely to be of growing importance.

88. Symeon C. Symeonides, Contracts Subject to Non-State Norms, 54 AM. J. ComP. L. 209, 211 (Supp. 2006).

89. One might also characterize such a decision as deference to the Commission on European Contract Law, the private group of independent experts that drafted these principles. See Symeon C. Symeonides, Party Autonomy and Private-Law Making in Private International Law: The Lex Mercatoria That Isn't 1-2 (Nov. 19, 2006) (unpublished manuscript), available at http://ssrn.com/abstract $=946007$.

90. See The Emergence of Private Authority in Global Governance (Rodney Bruce Hall \& Thomas J. Biersteker eds., 2002) (describing the growing role of private actors in global governance).

91. See SHANY, supra note 56 (describing the jurisdictional challenges posed by the spread of international courts). 


\section{B. Who Gets What? Judicial Determination of Rights and Obligations of Transnational Actors}

The second fundamental question of global governance is: Who gets what? ${ }^{92}$ In other words: Who enjoys which rights and who bears which obligations in transnational activity? Domestic courts help answer this question by determining rights and obligations of transnational actors with respect to each other and with respect to economic and political resources. ${ }^{93}$ This is the substantive global governance function of domestic courts.

It is well understood that the determination of rights and obligations is a basic function of courts. ${ }^{94}$ Courts are, after all, dispute resolvers, and litigation paradigmatically arises out of disputes over parties' respective rights and obligations. But the determination of rights and obligations is more than a dispute resolution function. When dispute resolution is based on rules, it becomes a form of regulation. ${ }^{95}$ From the perspective of political science, then, courts are important not only because they resolve discrete disputes, but also because they contribute to the authoritative allocation of resources within a society.

Neither legal scholars nor political scientists have systematically explored the implications of this judicial function for global governance. However, existing research on three types of transnational litigation provides a point of departure for doing so: transnational regulatory litigation, transnational public law litigation, and

92. The "who gets what" question has long preoccupied scholars of domestic systems of governance. See, e.g., Harold D. Lasswell, Politics: Who Gets What, When, How (1936); James A. Caporaso, Herbert P. Kitschelt, Erik M. Wibbels \& Steven I. Wilkinson, Introduction: Fortieth Anniversary Issue, 41 CoMP. POL. STUD. 405, 406 (2008) (focusing on "who gets what" as one of the fundamental questions of comparative politics). Here, I ask the question with respect to global governance.

93. Of course, constitutions and domestic legislation, as well as treaties and international custom, also play a critical role in the determination of rights and obligationsthey are the sources of many of the legal rules that courts interpret and apply in transnational litigation. By focusing on the role of domestic courts, I seek to highlight how domestic court decision making helps determine rights and obligations of transnational actors, not to downplay the importance of these legal sources.

94. See, e.g., Dahl, supra note 7, at 281 ("What groups are benefited or handicapped by the [United States Supreme] Court and how does the allocation by the Court of these rewards and penalties fit into our presumably democratic political system?"); Martin Shapiro, From Public Law to Public Policy, or the "Public" in "Public Law," 5 POL. SCI. \& Pol. 410, 413 (1972) (discussing "judicial allocation of values").

95. Cf. SHAPIRO, supra note 7, at 25 (arguing that as long as a judge acts to impose preexisting rules on the disputants, the judge is importing an element of social control).

96. Shapiro, supra note 94, at 412-13. 
transnational private litigation. This Part brings together these separate bodies of scholarship, making explicit a theme that is implicit in each of them: that domestic courts help determine rights and obligations of transnational actors, thus participating in the substantive regulation of transnational activity and influencing the allocation of economic and political resources.

\section{Transnational Regulatory Litigation}

"Transnational regulatory litigation" is litigation in which domestic courts apply domestic regulatory norms to determine the rights and obligations of transnational actors. ${ }^{97}$ As Hannah Buxbaum argues in her seminal article on the subject, this type of litigation enables domestic courts to "serve as an instrument of global economic regulation." ${ }^{98}$ For example, U.S. courts apply U.S. antitrust law to regulate global cartels and other anticompetitive transnational activity, ${ }^{99}$ U.S. securities laws to regulate cross-border securities fraud, ${ }^{100}$ and U.S. environmental law to address transnational environmental disputes. ${ }^{101}$ Insofar as these legal issues involve economic misconduct and harms to economic welfare, their judicial resolution affects how economic resources are allocated among transnational actors such as consumers, investors, and producers. ${ }^{102}$

\section{Transnational Public Law Litigation}

"Transnational public law litigation" is litigation in which "[p]rivate individuals, government officials, and nations sue one another directly, and are sued directly, in a variety of judicial fora, most

97. See Buxbaum, supra note 6, at 268 (defining transnational regulatory litigation as litigation in domestic courts involving the application of domestic regulatory norms that are shared by the international regulatory community to transnational activity, in a manner that provides global regulatory benefits). For my descriptive purposes, I adopt a broader definition of transnational regulatory jurisdiction, dropping the requirement that the domestic regulatory rules that are applied necessarily are shared by the regulatory community or have a beneficial effect on transnational activity.

98. Id. at 255.

99. Id. at $257-61$.

100. Id. at 271-78.

101. See generally Austen L. Parrish, Trail Smelter Déjà Vu: Extraterritoriality, International Environmental Law, and the Search for Solutions to Canadian-U.S. Transboundary Water Pollution Disputes, 85 B.U. L. REv. 363 (2005) (describing application of domestic environmental regulations by U.S. courts to cross-border environmental disputes)

102. Cf. Buxbaum, supra note 6, at 252-53 (referring to "application of regulatory law by domestic courts in situations involving global economic misconduct" in ways that can "marshal[] the resources of national courts in order to improve the global welfare"). 
prominently, domestic courts," based on rights derived from both domestic and international law. ${ }^{103}$ In the United States, the Alien Tort Statute (ATS), which gives federal district courts jurisdiction over any civil action brought by an alien for a tort committed in violation of international law, ${ }^{104}$ is the foundation for most transnational public law litigation. ${ }^{105}$ As the leading scholar of transnational public law litigation, Harold Koh, points out, plaintiffs in this type of litigation are frequently private individuals alleging human rights violations by government officials. ${ }^{106}$ However, private actors may also be subject to liability under the ATS for sufficiently "state-like or state-related activities." 107 Because transnational public law litigation rarely results in enforceable awards of monetary damages, domestic court decisions in these cases generally do not involve distribution of economic resources. $^{108}$ They do, however, declare the respective rights and obligations of transnational actors under human rights law. Moreover, when these declarations favor the plaintiff, the effect is to distribute a significant political resource: such declarations can be used as "a bargaining chip for use in other political fora" to influence governmental behavior. ${ }^{109}$

103. Koh, supra note 6, at 2348-49. As Anne-Marie Slaughter and David Bosco note, "Increasing numbers of individuals, including torture and terrorism victims, Holocaust survivors, and denizens of the dwindling Amazon rain forest, are now using lawsuits to defend their rights under international law [in U.S. courts]. The defendants in these cases include multinational corporations, foreign government officials, and even foreign states themselves." Anne-Marie Slaughter \& David Bosco, Plaintiff's Diplomacy, ForeIGN AfF., Sept./Oct. 2000, at 102, 102.

104. 28 U.S.C. $\$ 1350$ (2006) (providing that federal district courts have jurisdiction over any civil action brought by an alien for a tort committed in violation of international law).

105. See generally Ralph G. Steinhardt, The Internationalization of Domestic Law, in The Alien Tort Claims Act: An Analytical Anthology 3, 9 (Ralph G. Steinhardt \& Anthony D'Amato eds., 1999) (discussing litigation under the ATS). The seminal human rights case under the ATS is Filartiga v. Pena-Irala, 630 F.2d 876 (2d Cir. 1980).

106. See Harold Hongju Koh, The Haitian Refugee Litigation: A Case Study in Transnational Public Law Litigation, 18 MD. J. INT'L L. \& TRADE 1, 3 (1994).

107. Steinhardt, supra note 105 , at 9.

108. See Koh, supra note 6, at 2368 (" $[\mathrm{N}]$ o Filartiga-type plaintiff has apparently collected full compensation for his injuries ...."). However, insofar as the threat of ATS litigation induces monetary settlements, they may indirectly allocate economic resources among transnational actors. I thank Samuel Baumgartner for pointing this out. In fact, in June 2009, the Royal Dutch Shell company agreed to pay $\$ 15.5$ million to settle a transnational public law claim based on allegations that the company was complicit in the 1995 executions of environmental and human rights advocates in Nigeria. Robyn Dixon, Niger Delta Inhabitants See Compensation for Executions as a New Beginning, L.A. TIMES, June 10, 2009, http://www.articles.latimes.com/2009/jun/10/world/fg-nigeria-shell10.

109. Koh, supra note 6, at 2349. 


\section{Transnational Private Litigation}

An emphasis on public law, including domestic regulatory law and human rights law, runs the risk of obscuring the role of domestic private law in global governance. Private law-which includes the law of torts, contracts, and property - is just as much an instrument of regulation as public law. ${ }^{110}$ Indeed, "[ $\left.\mathrm{t}\right]$ he 'private' law of property and contract authoritatively allocates most of the values in a capitalist society." attention to "transnational private litigation," which he defines as litigation of private law claims by transnational actors in domestic courts. ${ }^{112}$

The policies underlying private law include compensation for harm, correction of market failures, and deterrence of undesirable activity. ${ }^{113}$ Thus, transnational private litigation can serve both distributive and regulatory functions. ${ }^{14}$ Disputes over property rights - including intellectual property rights - explicitly involve conflicting claims over economic resources. In such disputes, domestic courts distribute those resources by assigning property rights to one party or another. ${ }^{115}$ Transnational actors enter contracts to reduce their uncertainty about how they will share the costs and benefits of their economic transactions. In contract disputes, domestic

110. See Shapiro, supra note 94, at 413 (noting, for example, the law of torts, as well as "credit-debtor, landlord-tenant, seller-purchaser and a host of other areas of [private] law that set the balance of economic power between competing segments of a society"); see also Ronald A. Brand, Private Law and Public Regulation in U.S. Courts, in 2 Private LaW, Private INTERNATIONAL LAW, AND JUdicial COOPERATION IN THE EU-US RELATIONSHIP 115 (Ronald A. Brand ed., 2005) (explaining the public role of private litigation in the United States); Robert Wai, Transnational Liftoff and Juridical Touchdown: The Regulatory Function of Private International Law in an Era of Globalization, 40 COLUM. J. TRANSNAT'L L. 209, 232-38 (2002) (discussing the transnational regulatory function of domestic private laws).

111. Martin Shapiro, Public Law and Judicial Politics, in Political Science: The StATE OF THE Discipline II 365, 366 (Ada W. Finifter ed., 1993).

112. Wai, supra note 6 , at 244 (defining transnational private litigation as "transnational litigation of private law claims in national courts").

113. Robert Wai, Transnational Private Law and Private Ordering in a Contested Global Society, 46 HARv. INT'L L.J. 471, 474 (2005).

114. Wai, supra note 6, at 245.

115. On the economics of property law, see generally ROBERT COOTER \& THOMAS Ulen, LAW AND ECONOMICS chs. 4-5 (3d ed. 2000); Louis Kaplow \& Steven Shavell, Economic Analysis of Law 14-29 (Nat'1 Bureau of Econ. Research, Working Paper No. 6960, 1999), available at http://www.nber.org/papers/w6960. 
courts distribute these costs and benefits by determining how the contract is interpreted and whether it is enforced. ${ }^{116}$

In addition, transnational economic activity may generate externalities. That is, it may have effects on actors who do not have a contractual relationship with the person engaged in that activity. ${ }^{117}$ In tort disputes, domestic courts distribute the costs of negative externalities among transnational actors by determining the extent to which the party generating the externalities is obligated to compensate the party that bears the associated costs. ${ }^{118}$ At the intersection of transnational public law litigation and transnational private litigation are disputes involving the economic activity of sovereign states, including disputes over sovereign debt, ${ }^{119}$ disputes between states and foreign private investors, ${ }^{120}$ and, more generally, transnational litigation arising out of the commercial activity of foreign sovereigns. ${ }^{121}$ Thus, the contributions of domestic courts to global governance in transnational private litigation seem to be at least as important as in transnational regulatory litigation and transnational public law litigation.

In transnational regulatory litigation, domestic courts apply domestic regulations to transnational activity; in transnational public law litigation, they apply human rights law; and in transnational private litigation, they apply tort, property, and contract law. Notwithstanding these differences, in all three contexts, one sees the substantive global governance function of domestic courts: domestic court decisions determine rights and obligations of transnational actors and frequently influence the distribution of economic and political resources among those actors. This substantive function responds to the fundamental "who gets what" question in global governance. The jurisdictional

116. See, e.g., Joel R. Paul, The Isolation of Private International Law, 7 WIS. INT'L L.J. 149, 153 (1988) ("The [legal] realists showed that the rules of classical contract law represent the exercise of public power as much as the rules of antitrust law.').

117. See COOTER \& ULEN, supra note 115, at 290 (defining negative externalities as harms that occur outside a contractual relationship).

118. See, e.g., Shapiro, supra note 94, at 413-14 (noting that tort law "is anxious to define justice between man and man almost exclusively in terms of what treatment of individual litigants will best achieve preferred public goals").

119. See generally Lee C. Buchheit, G. Mitu Gulati \& Robert B. Thompson, The Dilemma of Odious Debts, 56 DuKE L.J. 1201 (2007).

120. See Jeswald W. Salacuse, Is There a Better Way? Alternative Methods of TreatyBased, Investor-State Dispute Resolution, 31 FordHAM INT'L L.J. 138 (2007) (analyzing the use of courts and alternative dispute resolution methods for resolving disputes between states and foreign private investors).

121. The U.S. federal courts have jurisdiction over some such suits under the Foreign Sovereign Immunities Act. 28 U.S.C. § 1605(a)(2) (2006). 
function discussed above responds to the "who governs" questionthat is: Who decides who gets what? These functions are summarized in Table 1.

Table 1.

The Global Governance Functions of Domestic Courts

\begin{tabular}{|l|l|l|}
\hline \multicolumn{1}{|c|}{ Function } & \multicolumn{1}{|c|}{$\begin{array}{c}\text { Associated } \\
\text { Governance Issue }\end{array}$} & \multicolumn{1}{|c|}{ Analytical Categories } \\
\hline $\begin{array}{l}\text { Jurisdictional: } \\
\text { Allocation of } \\
\text { Governance Authority }\end{array}$ & Who governs? & $\begin{array}{l}\text { Allocation among states, } \\
\text { between domestic and } \\
\text { international institutions, } \\
\text { and between private and } \\
\text { public institutions }\end{array}$ \\
& & $\begin{array}{l}\text { Allocation of } \\
\text { adjudicative, prescriptive, } \\
\text { and enforcement } \\
\text { authority }\end{array}$ \\
\hline $\begin{array}{l}\text { Substantive: } \\
\text { Determination of } \\
\text { Rights and } \\
\text { Obligations of } \\
\text { Transnational Actors }\end{array}$ & Who gets what? & $\begin{array}{l}\text { Transnational regulatory } \\
\text { litigation }\end{array}$ \\
& & $\begin{array}{l}\text { Transnational public law } \\
\text { litigation }\end{array}$ \\
& & Transnational private \\
& & litigation \\
\hline
\end{tabular}

III. The Transnational SHADOW OF THE LAW

The global governance functions of domestic courts discussed in Part II clearly matter for litigants. It goes without saying that the litigants care how domestic courts perform the substantive global governance function. After all, the judicial answer to the "who gets what" question determines the litigants' respective rights and obligations. The jurisdictional function of domestic courts-for example, judicial allocation of adjudicative authority - also matters for litigants. Kevin Clermont and Theodore Eisenberg find a strong "forum effect" in domestic litigation in U.S. federal courts: when the plaintiff's initial choice of forum is defeated, the chance of winning decreases substantially. ${ }^{122}$ Choice of forum is even more important in

122. Kevin M. Clermont \& Theodore Eisenberg, Litigation Realities, 88 CoRnELL L. REv. 119, 124 (2002). They find that plaintiffs' win rate in federal civil cases drops from 
transnational litigation, due to the "[s]hifting inconveniences and changing biases" associated with a move from a domestic court to a foreign court (or vice versa). ${ }^{123}$ Finally, transnational litigants care about the answer to the "who prescribes" question. Because legal rules vary substantially across states, which state's law applies can determine which side wins. ${ }^{124}$

This Part argues that the global governance functions of domestic courts are important not only because of their impact on litigants, but also - and perhaps even more importantly_-because of their influence beyond borders and beyond the parties to particular lawsuits. Domestic court decisions affect the behavior of transnational actors, including strategic behavior such as transnational bargaining and transnational forum shopping; they can either increase or reduce global economic welfare; and they can either hinder or provide support for other global governance institutions, including international institutions like international law and international courts, and private institutions like transnational contracting and transnational arbitration. These broader effects suggest that domestic courts play an important role in global governance. At the very least, the effectiveness of international and private forms of global governance depends significantly on the support of domestic courts.

To help highlight these broader implications of domestic court decision making, this Part takes Robert Mnookin and Lewis Kornhauser's well-known "shadow of the law" metaphor-used by them to elucidate the influence of divorce courts on the behavior of divorcing couples "outside the courtroom" transnational activity. Thus, the "transnational shadow of the law" refers to the effects of domestic courts that radiate beyond borders and beyond the parties to particular lawsuits. ${ }^{126}$

$58 \%$ in cases in which there is no transfer to $29 \%$ in transferred cases and, after controlling for all available variables, "[a] plaintiff's $50 \%$ odds would drop after transfer of venue to approximately $40 \%$." Id.

123. Kevin M. Clermon, The Role of Private International Law in the United States: Beating the Not-Quite-Dead Horse of Jurisdiction 8 (Cornell Law Sch. Legal Studies Research Paper Series, Paper No. 04-012, 2004), available at http://papers.ssrn.com/sol3/ papers.cfm?abstract_id $=588321$.

124. BORN \& RUTLEDGE, supra note 20, at 562.

125. Mnookin \& Kornhauser, supra note 14, at 951, 968, 972-73; see also Shapiro, supra note 14, at 329 ("[L]egalized bargaining under the shadow supervision of an available court ... is not purely mediatory, because the bargain struck will depend in part on the 'legal' strength of the parties, that is, predictions of how each would fare in court.").

126. Cf. Marc Galanter, The Radiating Effects of Courts, in EMPIRICAL THEORIES ABout CourTs 117, 121 (Keith O. Boyum \& Lynn Mather eds., 1983) (referring to "[t]he [r]adiating [e]ffects of [c]ourts" in the domestic context); Wai, supra note 110, at 267 


\section{A. Domestic Courts and the Strategic Behavior of Transnational Actors}

Domestic court decisions can affect the strategic behavior of transnational actors. Strategic behavior is behavior by one actor based on the anticipated behavior of other actors. ${ }^{127}$ Strategic behavior occurs when one actor's ability to further its goals depends on "how other actors behave." ${ }^{28}$ Under those conditions, its decisions must take into account the expected actions of those other actors. ${ }^{129}$ As game theorist James Morrow explains, "[a]n actor cannot simply choose a course of action that produces its preferred outcome because the choices of others also affect the final result." ${ }^{\prime \prime 30}$ Because actors generally do not know with certainty how others will behave, they typically infer future behavior from past behavior. ${ }^{131}$ Thus, strategic behavior is largely a function of available information upon which inferences can be made about the future behavior of others.

Applied to the transnational shadow of the law, the implication of this logic is that insofar as the ability of transnational actors to reach their goals depends on domestic court decisions, their behavior will be partly a function of their expectations about how domestic courts will make those decisions. These expectations in turn depend significantly on transnational actors' knowledge about prior domestic court decisions.

Having abstractly explained how domestic court decisions can affect the behavior of transnational actors, this Part will now illustrate this strategic logic in two contexts: transnational bargaining and transnational forum shopping. The first is an example of the strategic

(referring to the "shadow of the law" to describe the reliance of transnational arbitration on national legal systems). The definition of "transnational law" explicitly recognizes that domestic law can have transnational implications. See Jessup, supra note 15, at 1-2 (defining transnational law as law, whether domestic or international, public or private, "which regulates actions or events that transcend national frontiers"). The concept of the transnational shadow of the law complements the concept of transnational law by drawing attention to the transnational implications of domestic court decisionmaking and emphasizing the distinction between transnational legal doctrine and the domestic courts that interpret and apply it.

127. See David A. Lake \& Robert Powell, International Relations: A Strategic-Choice Approach, in Strategic Choice and International Relations 3, 3 (David A. Lake \& Robert Powell eds., 1999) (describing the strategic choice approach).

128. Id.

129. Id.

130. James D. Morrow, The Strategic Setting of Choices: Signaling, Commitment, and Negotiation in International Politics, in STRATEgIC CHOICE AND INTERNATIONAL RELATIONS, supra note 127, at 77, 77.

131. Lake \& Powell, supra note 127 , at 9. 
behavioral effects of the substantive global governance function of domestic courts (determination of rights and obligations of transnational actors), and the second is an example of the jurisdictional function (allocation of governance authority). ${ }^{132}$

\section{Bargaining in the Transnational Shadow of the Law}

First, domestic court decisions affect bargaining among transnational actors. Scholars have long argued that bargaining is a form of strategic behavior that depends on court decisions. ${ }^{133}$ Martin Shapiro and Alec Stone Sweet explain the basic logic as follows:

[B] argaining is facilitated by the knowledge of each party that, if the two do not reach a consensual resolution to the conflict, the other may go to court and seek an imposed outcome. Just as important, the previously judicially announced rules that will determine what a court will impose if litigation does occur fix the parameters within which the two parties bargain even if neither ever goes to court. The relative legal strengths of the two parties, as defined by those rules judicially announced to resolve previously litigated disputes, are crucial factors in determining the bargaining strengths of negotiating parties in other disputes that are not litigated but, in form, are resolved by purely private, consensual agreements. ${ }^{134}$

Similarly, bargaining among transnational actors depends on domestic court decisions. When a domestic court makes a decision that determines rights and obligations of transnational actors, the effect is not only particular and retrospective in the sense that it binds specific transnational actors (the litigants) regarding an existing dispute; it also is general and prospective, because the decision sends a signal to transnational actors that the court will make a similar decision under similar circumstances in the future. ${ }^{135}$ Thus, the substantive function of domestic courts in global governance has not only direct effects on the

132. Although this Part emphasizes the impact of domestic court decisions on the strategic behavior of transnational actors, it is important to note that domestic court decisions can also influence the normative, rule-based behavior of transnational actors. See generally James G. March \& Johan P. Olsen, The Institutional Dynamics of International Political Orders, 52 INT'L ORG. 943, 949-51 (1998) (comparing behavioral logic of consequences, which characterizes strategic choice, and the logic appropriateness, which characterizes norm-based decision making).

133. See, e.g., Mnookin \& Kornhauser, supra note 14 (explaining influence of court decisions on bargaining outside the courtroom); Shapiro, supra note 14 (same).

134. SHAPIRO \& SWEET supra note 7, at 213.

135. Alec Stone Sweet \& Thomas L. Brunell, Constructing a Supranational Constitution: Dispute Resolution and Governance in the European Community, 92 AM. PoL. SCI. REv. 63, 64 (1998). 
litigants, but also indirect shadow effects on the strategic behavior of transnational actors more generally.

In fact, sometimes plaintiffs are more interested in the strategic than the direct effects of transnational litigation, as in the case of transnational public law litigation. ${ }^{136}$ As Koh explains, judges may claim to be resolving only a particular dispute, but they are "actually declaring (or not declaring) international norms that litigants transport to other fora for use in political bargaining., ${ }^{, 137}$

\section{Transnational Forum Shopping}

Domestic court decisions allocating governance authority influence another form of strategic behavior: transnational forum shopping. ${ }^{138}$ When deciding where to file a lawsuit, plaintiffs consider, among other things, which state's laws are most favorable to their claim. ${ }^{139}$ For example, if the U.S. company AmeriCo decides to sue the Ruritanian company RuriCo, and AmeriCo believes it is more likely to win under U.S. law than under Ruritanian law, it may file its lawsuit in a U.S. court, even if the transnational activity giving rise to its dispute with RuriCo occurred primarily in Ruritanian territory. If U.S. courts tend to decide that U.S. law should apply in such circumstances, they would encourage this type of forum shopping. ${ }^{140}$ In contrast, if they instead tend to apply the law of the place of the underlying transnational activity (in this case, Ruritanian law), they would discourage this form of forum shopping by removing the advantage of more favorable U.S. law. ${ }^{141}$

136. See Koh, supra note 6, at 2349 (explaining that transnational public law plaintiffs pursue prospective aims - obtaining a judicial declaration of a norm that they can then use in bargaining - rather than strictly retrospective goals, such a obtaining damages).

137. Id. at 2395; see also Buxbaum, supra note 6, at 316 (explaining that transnational regulatory litigation "enable[s] national courts to participate in implementing effective regulatory strategies for global markets"); Wai, supra note 6, at 250 (noting that transnational private litigation can "introduce [new] policy values (sometimes through new policy actors) into political negotiations or decision making in other venues, domestic or international").

138. See Robert M. Cover, Narrative, Violence, And the Law 59 (Martha Minow, Michael Ryan \& Austin Sarat eds., 4th prtg. 1995) (describing the "strategic behavior entailed in forum shopping").

139. Andrew S. Bell, Forum Shopping and Venue in Transnational Litigation 24 (2003).

140. See Friedrich K. Juenger, Forum Shopping, Domestic and International, 63 TuL. L. REV. 553, 558-59 (1989) (explaining this relationship between choice of law and forum shopping).

141. See id. at 559 ("[T] he very purpose of the classical [e.g. lex loci delicti (place of the wrong)] conflicts system was the prevention of forum shopping."). 
Similarly, if U.S. courts tend to dismiss cases arising from extraterritorial activity, they would discourage this type of forum shopping. For example, in the United States, the forum non conveniens doctrine is widely understood as an "anti-forum-shopping device" because it allows a U.S. court to dismiss transnational litigation in favor of a more appropriate foreign court even if the U.S. court has jurisdiction. ${ }^{142}$

Legal doctrine - including choice of law rules and the forum non conveniens doctrine - may play an independent role in deterring forum shopping. But the real deterrent effect depends largely on how domestic courts actually apply those rules to allocate governance authority. ${ }^{143}$

\section{B. Domestic Courts and the Global Economy}

The manner in which domestic courts allocate governance authority also has implications for the global economy. For example, Michael Whincop and Mary Keyes suggest that by allocating adjudicative authority to those forums which entail the lowest litigation costs, domestic courts can enhance global efficiency. ${ }^{144}$ Alan Sykes implies that judicial allocation of adjudicative authority should be understood as a trade and investment issue. ${ }^{145}$ He argues that suits in U.S. courts against U.S. firms arising from activity occurring outside the United States can lead to discriminatory application of more stringent U.S. liability standards to the behavior of those firms. ${ }^{146}$ This discrimination causes welfare losses "to the degree that less efficient

142. Id. at 555-56; see also Russell J. Weintraub, Introduction to Symposium on International Forum Shopping, 37 TEX. INT'L L.J. 463, 464 (2002) (elucidating that the forum non conveniens doctrine "is an American defendant's primary defense against a forumshopping plaintiff").

143. The impact of domestic court decisions may also affect the public-private dimension of forum shopping. For example, one reason that transnational actors often select arbitration rather than litigation as a method of dispute resolution is that the domestic courts generally are more likely to enforce foreign arbitral awards than foreign court judgments. See BORN \& RUTLEDGE, supra note 20, at 1084.

144. See Michael J. Whincop \& Mary Keyes, Policy and Pragmatism in the CONFLICT OF LAWS 127, 127, 131 (2001) (arguing that "jurisdictional rules affect litigation costs" and that "[t]he efficient forum is the forum that minimises litigation costs"). As Whincop and Keyes explain, a domestic court can increase the likelihood that a plaintiff will make efficient forum choices by making decisions not to assert adjudicative authority when it is not the most efficient forum. Id. at 144.

145. Alan O. Sykes, Transnational Forum Shopping as a Trade and Investment Issue, 37 J. LEgAl STUD. 339 (2008). For example, he argues that judges' forum non conveniens decisions can help address the problem of welfare-reducing legal discrimination against U.S. firms that he identifies in his article. Id. at 368-70.

146. Id. at 340 
firms subject to lesser liability displace more efficient firms subject to greater liability." this welfare loss by "limiting foreign tort plaintiffs to the law and forum of the jurisdiction in which their harm arose." 148

Judicial allocation of prescriptive authority can also affect global economic welfare. According to law and economics theories of choice of law, choice of law rules have significant global economic consequences. ${ }^{149}$ Law and economics scholars generally posit one of two basic causal mechanisms to explain this relationship, one focusing on private conduct, the other on governmental conduct. First, they argue that choice of law rules create incentives for private transnational activity: if well designed, these rules promote transnational activity that increases global welfare; if poorly designed, they promote transnational activity that decreases global welfare. ${ }^{150}$ Second, building on theories of regulatory competition, they argue that choice of law rules create incentives for substantive lawmaking by governments: well designed choice of law rules promote adoption of efficient (and therefore welfare-enhancing) substantive laws, whereas poorly designed choice of law rules facilitate the persistence of inefficient substantive laws. ${ }^{151}$ In effect, law and economics scholars posit an explanatory variable, an intervening variable, and a dependent variable: they hypothesize that choice of law rules (the explanatory

147. Id. at 376 .

148. Id. at 340

149. See generally WhINCOP \& KeYES, supra note 144; Andrew T. Guzman, Choice of Law: New Foundations, 90 GeO. L.J. 883, 885-86 (2002); Ralf Michaels, Two Economists, Three Opinions? Economic Models for Private International Law-Cross-Border Torts as Example, in AN ECONOMIC ANALYSIS OF PRIVATE INTERNATIONAL LAW 143, 179 (Jürgen Basedow \& Toshiyuki Kono eds., 2006). Moreover, some scholars argue that because U.S. law generally favors plaintiffs more than foreign law, judicial assertion of U.S. prescriptive authority in lawsuits against U.S. businesses arising from activity occurring outside U.S. territory may put those businesses at a competitive disadvantage in the global economy. For arguments along these lines, see Jack L. Goldsmith \& Alan O. Sykes, Lex Loci Delictus and Global Economic Welfare: Spinozzi v. ITT Sheraton Corp., 120 HARV. L. REV. 1137 (2007); Gary Clyde Hufbauer \& Nicholas K. Mitrokostas, International Implications of the Alien Tort Statute, 7 J. INT'L ECON. L. 245 (2004); Alan O. Sykes, Transnational Tort Litigation as a Trade and Investment Issue (Jan. 2007) (unpublished manuscript), available at $\mathrm{http}: / / \mathrm{ssrn} . \mathrm{com} / \mathrm{abstract}=956668$. This reasoning implies that by deferring to the prescriptive authority of the state where the activity occurred, domestic courts could avoid this result.

150. See, e.g., Guzman, supra note 149, at 885-96; Michaels, supra note 149, at 153.

151. See, e.g., Guzman, supra note 149, at 897; Michaels, supra note 149, at 172 (noting that from the perspective of an "incentivizing" economic model, "[p]rivate international law rules are efficient in such a model if they give incentives to states to pass rules that in turn maximize overall efficiency as between individuals"). 
variable) influence private and governmental behavior (the intervening variable), which in turn affects global welfare (the dependent variable).

But there is another crucial intervening variable: domestic courts. The causal chain posited by law and economics scholars depends on courts allocating prescriptive authority predictably and in accordance with applicable choice of law rules. ${ }^{152}$ Insofar as domestic courts make choice of law decisions unpredictably or inconsistently with applicable choice of law rules, those rules are unlikely to have the hypothesized behavioral consequences and global economic impact. Regarding the predictability of choice of law outcomes, "If people cannot ascertain the applicable rule[], or if they have no way of knowing the probability that it will cover the conduct they contemplate, they are less able to conform their conduct to the rule and the state cannot use legal rules to influence their behavior." ${ }^{\text {,153 }}$ And if, as some skeptics suggest, choice of law rules do not significantly affect the choice of law decisions of domestic courts, ${ }^{154}$ then the connection between those rules and the global economy would seemingly be weak at best. ${ }^{155}$ In summary, whether or not choice of law rules have the global economic consequences hypothesized by law and economics scholars depends on how domestic courts actually allocate prescriptive authority and the extent to which they do so in accordance with those rules.

\section{Domestic Courts and Other Governance Institutions}

Domestic courts do not perform their governance functions in isolation. To the contrary, "[A] wide variety of forms of governance

152. See Michaels, supra note 149, at 156 (explaining that from the perspective of an economic private law model, "predictability enables parties to optimise their conduct vis-àvis the incentives set by the applicable tort rules"). (1991).

153. Lea Brilmayer, CONFLict Of LaWS: Foundations AND Future Directions 173

154. See, e.g., SCOLES ET AL., supra note 5, at 83 ("“[O]f all the factors that may affect the outcome of a conflicts case, the factor that is the most inconsequential is the choice-oflaw methodology followed by the court."' (quoting Symeonides, Choice of Law in American Courts in 1994: A View "from the Trenches," 43 AM J. CoMP. L. 1, 2 (1995))); Stewart E. Sterk, The Marginal Relevance of Choice of Law Theory, 142 U. PA. L. REV. 949, 951 (1994) ("[C]hoice of law theory exerts at best a marginal influence on choice of law decisions."). But see Whytock, Myth of Mess, supra note 6, at 764-74 (empirically challenging this skeptical view).

155. One might argue that formal choice of law doctrine, particularly when it takes the form of rules rather than standards, might itself influence strategic behavior independently from how domestic courts apply it. But to the extent that transnational actors have information suggesting that domestic courts do not make choice of law decisions in accordance with those rules, any such influence would seem to be diminished. 
exist next to each other."156 This Subpart analyzes the relationships between domestic courts and two other types of global governance institutions: international institutions, such as international law and international courts; and transnational private institutions, such as transnational contracting and transnational arbitration. The effectiveness of these institutions depends significantly on the support of domestic courts.

\section{Domestic Courts and International Institutions}

When scholars and pundits think about global governance, they tend to think primarily about international institutions, such as international law and international courts. But, as this Subpart argues, the development of international law, compliance with international law, and the effectiveness of international courts all depend significantly on domestic courts. This is another way in which domestic courts play a supporting role in global governance. ${ }^{157}$

\section{a. Domestic Courts and the Development of International Law}

Domestic courts contribute to the development of international law by ascertaining, interpreting, and, some would say, making international law. ${ }^{158}$ Article 38 of the Statute of the International Court of Justice - the most authoritative statement of the sources of international law ${ }^{159}$ - specifies that the primary sources of international law are international conventions, international custom, and general principles of law recognized by civilized nations. ${ }^{160}$ Domestic courts

156. Klaus Dingwerth \& Philipp Pattberg, Global Governance as a Perspective on World Politics, 12 Global Governance 185, 192 (2006).

157. See CONFORTI, supra note 6 , at 8 ("[T] he truly legal function of international law essentially is found in the internal legal systems of States."); FALK, supra note 6, at xi ("II]nternational tribunals are not consistently or conveniently available to resolve most disputes involving questions of international law. Domestic courts can help to overcome this structural weakness in the international legal system.”). In addition to the functions discussed below, Eyal Benvenisti and George Downs have drawn attention to the role of domestic courts in promoting the accountability of intergovernmental action. See generally Benvenisti \& Downs, supra note 6.

158. See JANIS, supra note 5, at 81 ("The decisions of judges ... have played a surprisingly important part in the development of international law."); MURPHY, supra note 59, at 147 (stating that domestic courts "can be very important in implementing, refining, and developing international law").

159. See Malcolm N. Shaw, International LaW 55 (4th ed. 1997).

160. Statute of the International Court of Justice art. 38, para. 1(d), June 26, 1945, 59 Stat. 1055, 1060, 3 Bevans 1153, 1157 [hereinafter ICJ Statute]. 
ascertain international law by analyzing these sources. ${ }^{161}$ These domestic court determinations can be used as evidence of international law. $^{162}$ It is in this sense that judicial decisions are, as article 38 provides, a "subsidiary means for the determination of rules of [international] law." ${ }^{, 163}$ But notwithstanding their subsidiary status, ${ }^{164}$ domestic court decisions can be of "immense importance" for international law. ${ }^{165}$ They are, for example, "extremely important in clarifying the existence of norms, such as whether a customary rule of international law has emerged." ${ }^{166}$

Domestic courts also contribute to the development of international law by interpreting treaties and principles of customary international law. ${ }^{167}$ In litigation under the Alien Tort Statute, U.S. courts interpret international law to determine whether alleged torts constitute "violation[s] of the law of nations or a treaty of the United States." 168 Regarding treaties in particular, Benedetto Conforti argues that "domestic courts generate a much greater body of case-law concerning the interpretation of treaties than do international tribunals." ${ }^{169}$ U.S. courts routinely interpret treaties in transnational litigation. ${ }^{170}$ In so doing, they give executive branch interpretations "great weight," but executive interpretations are "not conclusive.",

161. See JANIS, supra note 5, at 81 (noting that domestic courts "collecting the data necessary to establish or explicate rules drawn from the other three (and implicitly higher) sources of international law"); MURPHY, supra note 59, at 88 (positing that domestic courts "engage in a review of the other sources [of international law] (treaty, custom, general principles of law) and then reach conclusions as to what the law is"). The Supreme Court's classic statement of this judicial function is in The Paquete Habana, 175 U.S. 677, 700 (1900). Domestic courts sometimes are also called upon to determine whether or not a state's entry into an international agreement complied with domestic treaty-making rules and, consequently, whether a particular treaty is valid international law at all. See CONFORTI, supra note 6, at 84-88 (discussing cases in the United States and Europe where domestic courts held that international agreements were not validly concluded under domestic law and cases where domestic courts held that they were valid).

162. IAN BrownLIE, PrinCiPLES OF PUBliC InTERnATIONAL LAW 19 (5th ed. 1998).

163. ICJ Statute, supra note 160. "Judicial decisions" include decisions of national courts. SHAW, supra note 159 , at 87.

164. The phrase "subsidiary means" connotes that domestic court decisions are not formal sources of international law. BROWNLIE, supra note 162, at 19.

165. SHAW, supra note 159 , at 86 .

166. MURPHY, supra note 59, at 88; see also SHAW, supra note 159 , at 87 (noting that the decisions of national courts "may provide evidence of customary rules").

167. See MuRPHY, supra note 59, at 147.

168. 28 U.S.C. $\$ 1350$ (2006).

169. CONFORTI, supra note 6, at 104.

170. See MuRPHY, supra note 59, at 148 .

171. Sumitomo Shoji Am., Inc. v. Avagliano, 457 U.S. 176, 184-85 (1982). However, as David Sloss demonstrates, in the early years of U.S. constitutional history, the Supreme Court gave virtually no deference to executive branch treaty interpretation. David Sloss, 
They also place "considerable weight" on the interpretive decisions of the courts of other treaty signatories, ${ }^{172}$ giving rise to "a corpus of national court decisions ... that implements, refines, and develops international law."173

Given the fine line between ascertaining and interpreting international law on the one hand, and making international law on the other hand, domestic courts arguably play a significant, if controversial, role in international law creation. ${ }^{174}$ Melissa Waters describes one process by which this can occur:

[D]omestic courts and other domestic law-declaring fora articulate or champion a particular domestic norm at the transnational level. The norm is then picked up by other transnational actors, thus being diffused around the world and becoming part of the international legal discourse. If the norm becomes sufficiently embedded in a large number of other domestic or international legal regimes, it becomes the dominant normative standard on a given issue..$^{175}$

Domestic courts also contribute to the formation of international law insofar as their decisions constitute state practice, ${ }^{176}$ which, along with a sense of legal obligation, is necessary for the establishment of customary international law. ${ }^{177}$ More generally, domestic courts "may help mold rules through the collection of evidence of customary international law or the general principles of law."178

Judicial Deference to Executive Branch Treaty Interpretations: A Historical Perspective, 62 N.Y.U. ANN. SuRV. Am. L. 497, 498-99 (2007).

172. See, e.g., Air France v. Saks, 470 U.S. 392, 404 (1985) (stating that "we "find the opinions of our sister signatories to be entitled to considerable weight" and referring to a French court's decision to interpret the term "accident" in the Warsaw Convention on International Transportation by Air (quoting Benjamins v. British European Airways, 572 F.2d 913, 919 (2d Cir. 1978))).

173. MURPHY, supra note 59, at 149.

174. See JANIS, supra note 5, at 82 ("[T] he judge's ... most controversial function in international law has to do with rule formation, the role that most impinges upon the power of sovereign states.").

175. Melissa A. Waters, Mediating Norms and Identity: The Role of Transnational Judicial Dialogue in Creating and Enforcing International Law, 93 GEO. L.J. 487, 503 (2005); see also Robert B. Ahdieh, Between Dialogue and Decree: International Review of National Courts, 79 N.Y.U. L. REv. 2029, 2123 (2004) (arguing that through a process of dialectical review, domestic courts interact with international courts in a manner that leads to the development of international norms).

176. See CONFORTI, supra note 6, at 79; SHAW, supra note 159 , at 88.

177. See Restatement (Third) of Foreign Relations LaW of the United States $\S 102(2)(1987)$

178. JANIS, supra note 6 , at 82 . 


\section{b. Domestic Courts and Compliance with International Law}

Two of the principal mechanisms of state compliance with international law depend heavily on domestic courts: enforcement and internalization. ${ }^{179}$ Thus domestic courts can either facilitate or hinder compliance with international law. ${ }^{180}$ Domestic courts contribute to enforcement when they determine whether conduct violates international law. ${ }^{181}$ The paradigmatic example of this mechanism is decentralized enforcement of EU law through the domestic courts of EU member states. ${ }^{182}$ According to the doctrines of supremacy and direct effect of EU law, member states' courts not only give priority to EU law in conflicts with domestic law, but also allow private litigants to sue member states for violating EU law. ${ }^{183}$ Even U.S. courts have frequently applied a presumption in favor of judicial enforceability of treaty-based rights, although the status of this presumption is contested. ${ }^{184}$ The key point is that "compliance with international law relies not so much on enforcement mechanisms available at the international level, but rather on the resolve of domestic legal operators

179. Of course, not only courts, but also other domestic institutions, including executive and legislative institutions, and domestic politics more generally, play an important role in determining levels of compliance. See, e.g., Miles Kahler, Conclusion: The Causes and Consequences of Legalization, 54 INT'L ORG. 661, 673-77 (2000) (discussing the consequences of domestic institutions and domestic politics for compliance with international law).

180. See Buxbaum, supra note 6, at 254 (describing transnational public law litigation as "a means of marshaling the resources of national courts in order to enhance global compliance with international law").

181. See MURPHY, supra note 59.

States might absorb into their national law the international commitment, such that the international obligation merges into a national obligation. When this happens, national laws, regulations, and courts become available to strengthen compliance with the international commitment.... Once the international norm becomes operative in national law, national courts may become available for enforcement, including though [sic] action filed by individuals.... The overall effect is for the international obligation to become embedded in the national legal system, thereby allowing the use of that system ... to promote compliance.

Id. at 163 .

182. See Tanja A. Börzel, Participation Through Law Enforcement: The Case of the European Union, 39 COMP. POL. STUD. 128, 134-35 (2006).

183. RALPH H. Folsom, PRINCIPLES OF EUROPEAN UniON LAW 70-78 (2005).

184. See generally David Sloss, When Do Treaties Create Individually Enforceable Rights? The Supreme Court Ducks the Issue in Hamdan and Sanchez-Llamas, 45 Colum. J. TRANSNAT'L L. 20 (2006) (arguing against the claim that there is a presumption that treaties do not create judicially enforceable individual rights, and arguing that between 1789 and 1975, the Supreme Court frequently applied a presumption in favor of domestic judicial remedies and that the current status of this presumption remains unresolved). 
such as ... judges to use to their limits the mechanisms provided by municipal law to ensure compliance with international norms." 185

But enforcement is not the only path toward compliance with international law. According to transnational legal process theory, an even more fundamental process leading to compliance is internalization. ${ }^{186}$ As Harold Koh argues, the key to compliance-or, as he calls it, "obedience"-is a process of "interaction and interpretation whereby international norms become domesticated and internalized into domestic law." ${ }^{\text {"187 }}$ One of the principal forms of internalization is judicial internalization, whereby "litigation in domestic courts provokes judicial incorporation of international law norms into domestic law, statutes, or constitutional norms.",188 By incorporating international law, domestic courts can promote internalization and enhance compliance; by declining to do so, they can frustrate internalization and hinder compliance.

\section{c. Domestic Courts and the Effectiveness of International Courts}

The effectiveness of international courts also depends significantly on domestic courts. As a general proposition, levels of compliance with the decisions of an international court are likely to be higher when the international court is embedded in domestic legal systems. ${ }^{189}$ An important dimension of embeddedness is the ability and willingness of domestic courts to recognize and enforce the judgments of the international court. ${ }^{190}$ This aspect of embeddedness can vary, with compliance increasing as domestic courts become more able or willing to recognize and enforce international court judgments.

185. CONFORTI, supra note 6, at 8-9.

186. See generally Harold Hongju Koh, Bringing International Law Home, 35 Hous. L. REv. 623 (1998) [hereinafter Koh, Bringing IL Home] (outlining transnational legal process theory); Harold Hongju Koh, Why Do Nations Obey International Law?, 106 YALE L.J. 2599, 2657 (1997) (same).

187. Koh, Bringing IL Home, supra note 186, at 636.

188. Id. at 643 .

189. Laurence R. Helfer, Redesigning the European Court of Human Rights: Embeddedness as a Deep Structural Principle of the European Human Rights Regime, 19 EUR. J. INT'L L. 125, 131 (2008).

190. Id. at 133 ("Embeddedness ... significantly improves the prospects for compliance with the European Convention [on Human Rights] ... by enabling national courts to protect the Convention's civil and political liberties ...."); Robert O. Keohane, Andrew Moravcsik \& Anne-Marie Slaughter, Legalized Dispute Resolution: Interstate and Transnational, 54 INT'L ORG. 457, 468-70 (2000) (defining the "embeddedness" of an international legal system in terms of the ability of national courts to enforce international judgments against their own governments). 
When a domestic court accepts an international court ruling, the compliance pull of that ruling becomes particularly strong: "[G]overnments find it much harder to disobey their own courts compared to international tribunals." ${ }^{\prime 191}$ Thus, by accepting (or not accepting) international court decisions, domestic courts can facilitate (or hinder) efforts to govern transnational activity through international courts.

The European Court of Justice (ECJ), the EU's principal judicial organ, owes its effectiveness largely to the domestic courts of EU member states. ${ }^{192}$ In fact, the ECJ "deliberately wooed national courts," the EU's preliminary reference procedure and to apply its interpretations of that law. ${ }^{194}$ Not all EU member state governments were eager to accept the ECJ's authority. ${ }^{195}$ But by obtaining the support of domestic courts, the ECJ increased the likelihood of member state compliance with its rulings: governments may have been willing to ignore the ECJ, but they were not willing to ignore their own national courts. ${ }^{196}$ As one EU law expert puts it, "the outer limits of the [ECJ's] authority and credibility are really to be found among the national judiciaries" of EU members. ${ }^{197}$

There is nothing inevitable about domestic court support for international courts. In the EU context, member states' domestic courts use references to the ECJ to challenge domestic law, but they "also use domestic legal avenues to challenge ECJ jurisprudence with which they disagree." 198 And in the United States, a practical

191. J.H.H. Weiler, A Quiet Revolution: The European Court of Justice and Its Interlocutors, 26 COMP. POL. STUD. 510, 519 (1994).

192. See FolsOM, supra note 183 , at $87-88$.

193. Laurence R. Helfer \& Anne-Marie Slaughter, Toward a Theory of Effective Supranational Adjudication, 107 YALE L.J. 273, 387 (1997).

194. See Stone Sweet \& Brunell, supra note 135, at 66.

195. ALTER, supra note 7, at 219-20.

196. Id. at 63. As Alter argues, "National judicial support gives the ECJ greater autonomy from states ... because if the ECJ can carry the support of national courts, it can be confident that its decisions will be accepted by national governments." Id.

197. Ralph H. Folsom, Law-Making and Litigation in the European Union, in EUROPEAN UNION LAW AfTER MAASTRICHT: A PracticAl GUIDE FOR LAWYERs OUTSIDE THE COMMON MARKET 24 (Ralph H. Folsom, Ralph B. Lake \& Ved P. Nanda eds., 1996); see also Alec Stone Sweet, Governing with Judges: Constitutional Politics in Europe 164 (2000) ("The success of the ECJ's gambit depended heavily on the willingness of national judges to use the article 177 [preliminary reference] procedure, and to faithfully implement the ECJ's interpretations of EC law.").

198. ALTER, supra note 7, at 61 ; see also id. at 63 ("[T] he support of national courts cannot be assumed, and maintaining this support is not easy. In the final analysis national courts are still loyal to their constitutions and to domestic political concerns."). 
consequence of the Supreme Court's 2008 holding in Medellin v. Texas that decisions of the ICJ are not directly enforceable in the United States may be to hinder efforts to have the ICJ play a leading role in governing consular affairs under the Vienna Convention. ${ }^{199}$

Using courts like the ECJ as case studies, scholars of comparative politics and international relations have highlighted the transformative effects that international courts can have on global governance. ${ }^{200}$ But the foregoing analysis suggests that whether international courts are likely to have such effects depends largely on whether they enjoy the support of domestic courts.

\section{d. The Relationship Between Domestic Courts and International Institutions}

What does the foregoing analysis mean for the relationship between domestic courts and international institutions? On the one hand, the analysis suggests that the success of efforts to govern transnational activity through international law and international courts depends significantly on the support of domestic courts. By offering such support, domestic courts can facilitate these efforts; by denying it, they can hinder them. In this sense, domestic courts play an important role in global governance through international institutions.

But domestic courts are not, of course, the only actors upon which the efficacy of international institutions depends. ${ }^{201}$ Moreover, the relationship between domestic courts and international institutions is not one-way: the latter can also provide support for the former. For example, international agreements dealing with transnational litigation-such as the Hague Service Convention ${ }^{202}$ and the Hague Evidence Convention ${ }^{203}$ - facilitate the contributions of domestic

199. 128 S. Ct. 1346 (2008); see also Martinez, supra note 6, at 494 ("U.S. courts applying international law will sometimes follow decisions of international courts on relevant issues. But sometimes, they do not ....”).

200. See, e.g., Courts Crossing Borders: Blurring the Lines of Sovereignty, supra note 7; Rachel A. Cichowski, Introduction: Courts, Democracy, and Governance, 39 COMP. POL. STUD. 3, 7 (2006).

201. See CONFORTI, supra note 6, at 8-9 (discussing not only the role of domestic courts, but also other "domestic legal operators"); Koh, Bringing IL Home, supra note 186, at 649-51 (including not only domestic courts, but also legislatures, nongovernmental organizations, and other entities as "law-declaring fora" that contribute to the internalization of international norms).

202. The Hague Convention on Service Abroad of Judicial and Extrajudicial Documents in Civil and Commercial Matters, Nov. 15, 1965, 20 U.S.T. 361, 658 U.N.T.S. 163.

203. The Hague Convention on the Taking of Evidence Abroad, Mar. 18, 1970, 23 U.S.T. 2555, 847 U.N.T.S. 231. 
courts to global governance by providing mechanisms for mutual assistance in transnational litigation. In the EU, the preliminary reference procedure not only enhances the ECJ's authority, but also supports the domestic courts of EU member states by helping them resolve issues of EU law. And while the domestic courts of EU member states may have played a central role in the construction of the EU legal system, it was two legal principles developed by the ECJthe doctrines of supremacy and direct effect of EU law - that provided doctrinal foundations for that role. ${ }^{204}$

In summary, it is impossible to have a sound understanding of international institutions - particularly international law and international courts - without a sound understanding of their relationships with domestic courts. Conversely, to understand the role of domestic courts in global governance, one must understand how this role relates to international institutions.

\section{Domestic Courts and Transnational Private Institutions}

Legal scholars and political scientists have highlighted the growing role of private institutions in global governance. ${ }^{205}$ This Subpart argues that the effectiveness of these institutions, like that of international institutions, depends significantly on the support of domestic courts. For example, transnational contracting and transnational arbitration rely on domestic courts.

a. Domestic Courts and Transnational Contracting

A basic transnational private institution is transnational contracting. ${ }^{206}$ Contractually governed activity creates a demand for third-party dispute resolution. ${ }^{207}$ Without third-party dispute resolution, "the costs of exchange may be prohibitive, since each prospective party may doubt that the other will abide by promises

204. See Stone Sweet \& Brunell, supra note 135, at 66 (claiming that by announcing the doctrines of supremacy and direct effect of EC law, "the ECJ supplied national courts with enhanced means of guaranteeing the effectiveness of EC law").

205. See, e.g., A. Claire Cutler, Private Power and Global Authority: Transnational Merchant LaW in the Global Political Economy (2003); Hall \& BIERSTEKER, supra note 90; Tim Büthe, Governance Through Private Authority: Non-State Actors in World Politics, 58 J. INT'L AfF. 281 (2004); Walter Mattli \& Tim Büthe, Global Private Governance: Lessons from a National Model of Setting Standards in Accounting, 68 LAW \& Contemp. Probs. 225 (2005); Walter Mattli, Private Justice in a Global Economy: From Litigation to Arbitration, 55 INT'L ORG. 919 (2001).

206. See STONE SwEET, supra note 197, at 14.

207. Stone Sweet \& Brunell, supra note 135, at 63-64. 
made over the life of the contract." ${ }^{208}$ By providing transnational dispute resolution services, domestic courts help meet this demand, providing important support for transnational contracting as a form of private governance. But insofar as domestic courts decline to enforce transnational contracts, they can hinder efforts to govern transnational activity through private contracting.

\section{b. Domestic Courts and Transnational Arbitration ${ }^{209}$}

Domestic courts are not, however, the only providers of transnational dispute resolution services. An alternative is transnational arbitration. Transnational arbitration is dispute resolution by a private actor (the arbitrator) pursuant to the agreement of the disputants to submit their dispute to arbitration. ${ }^{210}$ As such, transnational arbitration is a form of transnational private governance. ${ }^{211}$ By providing transnational dispute resolution services, transnational arbitration can facilitate governance through transnational contracting. ${ }^{212}$

But transnational arbitration itself depends significantly on domestic courts. This point was recognized by the architects of the modern system of transnational arbitration, ${ }^{213}$ and embodied in articles II and III of the United Nations Convention on Recognition and Enforcement of Foreign Arbitral Awards (the New York Convention), which creates a general rule in favor of judicial enforcement of arbitration agreements and arbitral awards, subject only to specified exceptions. $^{214}$ Today, there is a widespread understanding that

208. Id. at 64 .

209. For a more comprehensive statement of this Part's argument, see Whytock, supra note 18 , at $464-69$.

210. See Born \& RutLedGe, supra note 20, at 1083.

211. See Alec Stone Sweet, The New Lex Mercatoria and Transnational Governance, 13 J. EuR. PUB. POL'Y 627, 627 (2006) (arguing that together transnational arbitration and lex mercatoria constitute emerging private system of governance).

212. Cf. Shapiro \& Stone Sweet, supra note 7, at 323, 328-39 (noting that traders can choose between state and nonstate dispute resolution to facilitate their contractual exchanges).

213. See Albert Jan VAn den Berg, The New York Arbitration Convention of 1958: TOWARDS A UNIFORM JUdiCIAL INTERPRETATION 1 (1981) (calling the New York Convention the "cornerstone of current international commercial arbitration"); Thomas E. Carbonneau, The Ballad of Transborder Arbitration, 56 U. MiAMI L. REV. 773, 774-75 (2002) ("Sovereign state cooperation was indispensible to instituting the process. [Transnational commercial arbitration] needed the approbation of states to benefit from municipal courts' status of legitimacy and their authority in order to function effectively as a transborder system.").

214. Exceptions to the general rule in favor of enforcement of arbitration agreements are in article II, and exceptions to the general rule in favor of enforcement of arbitral awards are in articles $\mathrm{V}$ and VI. 
transnational arbitration depends on domestic courts, particularly for enforcement. $^{215}$

This does not mean that arbitration agreements and arbitral awards necessarily go unheeded without judicial recourse. Rather, because domestic courts generally have narrowly construed the New York Convention's exceptions to enforcement, ${ }^{216}$ transnational actors expect domestic courts to enforce arbitration agreements and arbitral awards, and are therefore more likely to comply with them voluntarily. ${ }^{217}$ It is as much by creating these expectations as by providing enforcement in particular cases that domestic courts support arbitration as a system of transnational private governance. ${ }^{218}$ In fact, one reason for the tremendous growth of transnational arbitration as an alternative to litigation is that transnational actors perceive that domestic courts are more likely to enforce arbitral awards than foreign court judgments. ${ }^{219}$

Judicial support of transnational arbitration is not inevitable, however. Insofar as they are reluctant to enforce arbitration agreements and arbitral awards, domestic courts may hinder rather than facilitate this private form of governance. Indeed, one recent empirical analysis suggests that in published decisions, U.S. courts may not be as likely to enforce transnational arbitral awards as often as

215. See, e.g., W. Michael ReISMAN, Systems of Control In InTERnAtional ADJUDICATION AND ARBITRATION: BREAKDOWN AND REPAIR 107 (1992) (arguing that arbitration relies on domestic courts); Carbonneau, supra note 213, at 801-03 (same); AnneMarie Slaughter, International Law in a World of Liberal States, 6 EuR. J. INT'L L. 503, 519 (1995) (same); Wai, supra note 6, at 247 (same). In theory, as an alternative to judicial enforcement, private enforcement of arbitration agreements and arbitral awards might be possible based on reputational sanctions. Bruce L. Benson, Arbitration in the Shadow of the Law, in 1 New Palgrave Dictionary of Economics and the Law 93, 95 (Peter Newman ed., 1998); David Charny, Nonlegal Sanctions in Commercial Relationships, 104 HARv. L. REV. 373 (1990); Stone Sweet, supra note 212, at 325. In practice, however, this is likely only in relatively small, well-defined and enduring communities in which actors have long time horizons and are able to monitor each other closely. Whytock, supra note 18, at 464-69.

216. GARY B. BORN, INTERNATIONAL ARBITRATION AND FORUM SElECTION Agreements: Planning, Drafting And Enforcing 113 (1999); Born \& Rutledge, supra note 20, at 1111 (citing Mitsubishi Motors Corp. v. Soler Chrysler-Plymouth, Inc., 473 U.S. 614 (1985); Scherk v. Alberto-Culver Co., 417 U.S. 506 (1974)).

217. See Christopher A. Whytock, The Arbitration-Litigation Relationship in Transnational Dispute Resolution: Empirical Insights from the U.S. Federal Courts, 2 World ARB. \& MEDIATION Rev. 39, 74 (2008) (finding that the U.S. district courts enforce arbitration awards covered by the New York Convention more often than not in published decisions).

218. Whytock, supra note 18 , at 464-69.

219. Cf. BORN \& RUTLEDGE, supra note 20, at 1084 ("[I]nternational arbitration is often seen as a means of obtaining an award that is more readily enforceable than a national court judgment.'). 
commonly believed. ${ }^{220}$ The important point is that, depending on their decisions, domestic courts can either support or undermine arbitration as a form of transnational private governance.

\section{c. The Relationship Between Domestic Courts and Transnational Private Institutions}

The foregoing analysis suggests that the success of efforts to govern transnational activity through transnational private institutions depends significantly on the support of domestic courts. By providing support - for example, by enforcing contracts, arbitration agreements, and arbitral awards - domestic courts can facilitate transnational private governance. By withholding this support, they can hinder it. Domestic courts thus play a foundational role in global governance through transnational private institutions.

But domestic courts also critically depend on private actors. Because courts generally cannot act on their own initiative, they depend on litigants to give them opportunities to make authoritative decisions. $^{221}$ Private plaintiffs play an important role in activating transnational litigation, and it is in transnational litigation that domestic courts perform their primary global governance functions. ${ }^{222}$ Therefore, beyond understanding transnational judicial governance and transnational private governance as distinct forms of global governance, it is important to understand the complex two-way relationship between them. ${ }^{223}$

220. See Whytock, supra note 217 , at 74 (finding that the full enforcement rate in published U.S. federal court decisions involving awards covered by the New York Convention is $73.9 \%$ and that in $3.0 \%$ of such decisions "the court either partially enforced an award or stayed enforcement proceedings").

221. See Shapiro \& StONE SweEt, supra note 7, at 293 ("[L]itigants activate courts ....”); Hannah L. Buxbaum, The Private Attorney General in a Global Age: Public Interests in Private International Antitrust Litigation, 26 YALE J. INT'L L. 219 (2001) (discussing the role of private litigants in judicial regulation of transnational economic activity); Cichowski, supra note 200, at 7 ("[E]xtending public access to courts can increase citizen and interest group participation in the development, monitoring, and enforcement of laws ....").

222. For example, the domestic courts of EU member states play a fundamental role in the EU legal system, but this role depends importantly on the willingness of private parties to litigate EU issues in those courts. See, e.g., ALTER, supra note 7; STONE SwEET, supra note 7, at 263-64; Anne-Marie Burley \& Walter Mattli, Europe Before the Court: A Political Theory of Legal Integration, 47 INT'L ORG. 41 (1993).

223. Cf. Büthe, supra note 205, at 284 ("This leaves the question[s]: What is the role of the state in this empowerment of private actors? And can states take back the authority thus granted to private actors? ... Does the increase in private authority have a lasting effect on the role of states in international governance?'). 


\section{GOVERNANCE-ORIENTED ANALYSIS}

This Article has argued that domestic courts play an important role in global governance. ${ }^{224}$ But because scholars have devoted relatively little attention to this role, we know little about how domestic courts behave as global governors, why they govern the way they do, and how they affect transnational activity. ${ }^{225}$ This lack of understanding prevents sound critical evaluation of the contributions of domestic courts to global governance and well-informed decisions about the most appropriate governance arrangements for different realms of transnational activity. This Part argues that to address this gap in knowledge, scholars should do two things. First, they should analyze not only transnational legal doctrine, but also transnational law in action. Second, they should move beyond litigant-oriented perspectives to analysis of the transnational shadow of the law. This approach-which this Article calls "governance-oriented analysis"has descriptive, positive-theoretical, and normative goals. ${ }^{226}$

\section{A. Methodological Characteristics}

Governance-oriented analysis has two basic methodological characteristics: a focus on transnational law in action as a complement to doctrinal analysis and a focus on the transnational shadow of the law as a complement to litigant-oriented analysis.

1. Transnational Law in Action: Governance-Oriented Analysis as a Complement to Doctrinal Analysis

Resisting preoccupation with international law, Philip Jessup argued in 1956 for an alternative conception of "the law applicable to the complex interrelated world community.,227 He proposed the concept of "transnational law," which he defined as the body of law that "regulates actions or events that transcend national frontiers," a concept meant to embody both public and private international law. ${ }^{228}$ Challenging the distinction between national and international as a

224. Supra Parts II-III.

225. But see sources cited supra note 6 (describing related prior scholarship).

226. For examples of governance-oriented analysis, see Whytock, supra note 18 (preliminary governance-oriented analysis of transnational arbitration); Whytock, supra note 217 (same); Whytock, Myth of Mess, supra note 6 (governance-oriented analysis of international choice of law). Tonya Putnam's important study of extraterritorial application of U.S. law, supra note 6, also has the attributes of governance-oriented analysis.

227. JESSUP, supra note 15, at 1 (internal quotation marks omitted).

228. Id. at 2 . 
basis for legal classification, he also specifically included in his definition domestic legal rules that apply to transnational activity. ${ }^{229}$ The definition of transnational law thus explicitly recognizes that domestic legal doctrine can have transnational implications.

Governance-oriented analysis complements the study of transnational legal doctrine with analysis of transnational law in action - that is, analysis of how domestic courts actually interpret and apply transnational law to allocate governance authority and determine rights and obligations of transnational actors. ${ }^{230}$

The underlying assumption is that legal doctrine alone does not adequately account for what judges do. ${ }^{231}$ In this way, governanceoriented analysis extends core realist insights to transnational law ${ }^{232}$ and also has an affinity with the New Haven school of international law, which seeks to provide, "in lieu of anecdotal historicism, for the systematic description of past trends in decision in terms of their approximations to clarified goals." ${ }^{233}$

To analyze transnational law in action, governance-oriented analysis uses qualitative and statistical methods of descriptive and

229. Id. at $70,106$.

230. See Pound, supra note 15, at 15 (illustrating the importance of the distinction between "law in books" and "law in action").

231. See, e.g., Tracey E. George \& Lee Epstein, On the Nature of Supreme Court Decision Making, 86 AM. POL. SCI. REv. 323 (1992) (reviewing and refining empirical analyses, suggesting that nonlegal factors, including judges' ideological attitudes, also influence judicial decision making).

232. See Karl N. Llewellyn, Some Realism About Realism-Responding to Dean Pound, 44 Harv. L. Rev. 1222, 1236-37 (1931) (attributing to the legal realist movement a "[d]istrust of traditional legal rules and concepts insofar as they purport to describe what either courts or people are actually doing" and "a distrust of the theory that traditional prescriptive rule-formulations are the heavily operative factor in producing court decisions"). Although my approach is indeed skeptical insofar as it treats the extent and nature of the influence of legal rules on the decisions of courts and other actors as questions to be investigated empirically in various settings rather than things to be assumed, my approach takes seriously the role of transnational law in influencing the behavior of domestic courts as global governors. As Llewellyn himself emphasized, "“distrust' in this ... point is not at all equivalent to "negation in any given instance." Id. at 1237; see also Howard Erlanger et al., Is It Time for a New Legal Realism?, 2005 WIS. L. REV. 335, 343 ("[L]egal realism originally had a purely domestic focus, but now it is impossible for legal scholars to ignore transnational issues and arenas. One of the key tests of New Legal Realism will be its success in taking on major issues involved with the so-called 'globalization of law."'); Gregory Shaffer, $A$ New Legal Realism: Method in International Economic Law Scholarship, in INTERNATIONAL Economic LaW - The State \& Future of THE Discipline (Colin B. Picker, Isabella Bunn \& Douglas Arner eds., 2009) (discussing new legal realist approaches to the analysis of international economic law).

233. Myres S. McDougal, Some Basic Theoretical Concepts About International Law: A Policy-Oriented Framework of Inquiry, 4 J. CONFLICT RESOL. 337, 344 (1960). 
causal inference ${ }^{234}$ and draws on positive theories of judicial decision making developed by political scientists and legal scholars. ${ }^{235}$ Analysis based solely on anecdotal examples or "big" cases is unlikely to be reliable. What is needed instead is systematic examination of broad patterns of judicial decision making in transnational litigation, particularly decision making by the lower courts, which are on the front lines of transnational litigation. ${ }^{236}$

With its focus on transnational law in action, domestic court decision making is a key dependent variable in governance-oriented analysis. Yet just as an exclusive focus on transnational legal doctrine is insufficient from a governance-oriented perspective, so is an exclusive focus on law in action. To adopt the Holmesean equation of law with "[t]he prophecies of what the courts will do in fact" conflate what the governance-oriented approach wants to explain (the behavior of courts as global governors) with a potentially important explanatory variable (legal doctrine), making inferences about doctrinal effects impossible. ${ }^{238}$ Likewise, because there are important actors other than courts that influence and are influenced by transnational law, an exclusive focus on courts is insufficient. Thus, governance-oriented analysis emphasizes transnational law in action, particularly domestic court decision making in transnational litigation-but it does so as a complement to, not a substitute for, doctrinal analysis and analysis of the legal behavior of noncourt actors.

234. See Gary King, Robert O. Keohane \& Sidney Verba, Designing Social INQUIRY: SCIENTIFIC INFERENCE IN QUALITATIVE RESEARCH ch. 2 (1994); Lee Epstein \& Gary King, The Rules of Inference, 69 U. CHI. L. REV. 1, 29-37 (2002) (explaining these methods).

235. See generally George \& Epstein, supra note 231 (discussing these theories).

236. For steps in this direction, see, for example, Jeffrey Davis, Justice Without Borders: Human Rights Cases in U.S. Courts, 28 LAW \& POL'Y 60 (2006) (explaining judicial decision making in Alien Tort Statute claims); Putnam, supra note 6 (extraterritorial application of domestic law by U.S. courts); Kirk A. Randazzo, When Liberty and Security Collide: Foreign Policy Litigation and the Federal Judiciary, 94 KY. L.J. 629 (2005-2006) (decisions balancing national security and individual rights); Whytock, Myth of Mess, supra note 6 (international choice of law decision making by U.S. district courts); Whytock, supra note 217 (transnational arbitral award enforcement decisions by U.S. district courts).

237. Oliver Wendell Holmes, The Path of the Law, 10 HARv. L. Rev. 457, 461 (1897).

238. Cf. Martha Finnemore \& Kathryn Sikkink, International Norm Dynamics and Political Change, 52 INT'L ORG. 887, 892 (1998) ("Because one central question of norms research is the effect of norms on state behavior, it is important to operationalize a norm in a way that is distinct from the state or nonstate behavior it is designed to explain."). Holmes' approach is also problematic because the common conception of the rule of law as including among its values judicial decision making in accordance with recognized legal principles becomes incoherent if judicial decision making and law are not kept analytically distinct. 
2. The Transnational Shadow of the Law: Governance-Oriented Analysis as a Complement to Litigant-Oriented Analysis

Unsurprisingly, legal scholarship tends to focus on the implications of court decisions for litigants. But the global governance functions of domestic courts are important not only because of their impact on litigants, but also - and perhaps even more importantlybecause of their influence beyond the parties to particular lawsuits and beyond state borders. ${ }^{239}$ Therefore, to understand the role of domestic courts in global governance, scholars must complement litigantoriented analysis with analysis of the transnational shadow of the law. This is the second methodological characteristic of governanceoriented analysis.

To understand the transnational shadow of the law is to understand cause-and-effect relationships: domestic court decision making is an explanatory variable that affects transnational activity. ${ }^{240}$ How are scholars to improve their understanding of these relationships? Again, qualitative and statistical methods of inference must play a central role. Empirical scholarship by economists and political scientists on comparative political economy provides some clues about how these methods might be applied to shed light on the transnational shadow of the law. ${ }^{241}$ Among other things, these scholars have developed and empirically tested hypotheses about the relationships between cross-national variations in corporate and securities laws and corporate valuations, ${ }^{242}$ and between cross-national differences in the quality of domestic legal institutions on the one hand and international trade flows ${ }^{243}$ and foreign direct investment ${ }^{244}$ on the other hand. A major difference between these approaches and

239. See discussion supra Part III.

240. Although I am highlighting the question of causation, there may also be important constitutive dimensions to the relationship between domestic courts and transnational actors.

241. See generally Christopher A. Whytock, Taking Causality Seriously in Comparative Constitutional Law: Insights from Comparative Politics and Comparative Political Economy, 41 LoY. L.A. L. REV. 629 (2008) (reviewing empirical work on comparative political economy).

242. See, e.g., Thorsten Beck \& Ross Levine, Legal Institutions and Financial Development (World Bank Policy Research, Working Paper No. 3136, 2003), available at http://ssrn.com/abstract $=636556$.

243. See, e.g., Daniel Berkowitz et al., Legal Institutions and International Trade Flows, 26 Mich. J. INT'L L. 163 (2004).

244. See, e.g., Christian Daude \& Ernesto Stein, The Quality of Institutions and Foreign Direct Investment, 19 ECON. \& POL. 317 (2007); Amanda Perry, Effective Legal Systems and Foreign Direct Investment: In Search of the Evidence, 49 INT'L \& CoMP. L.Q. 779 (2000). 
governance-oriented analysis of transnational law is that the former often use formal laws and static descriptions of legal institutions as explanatory variables, whereas governance-oriented analysis should emphasize theoretically relevant categories of domestic court decision making as explanatory variables. ${ }^{245}$ Nevertheless, empirical comparative political economy scholarship suggests that this dimension of governance-oriented analysis is promising.

An implication of the focus on the transnational shadow of the law is that published court decisions are particularly relevant to governance-oriented analysis. It is well known that most court decisions are unpublished and that published decisions are not necessarily representative of the overall population of published and unpublished decisions. ${ }^{246}$ But beyond the litigants in particular lawsuits, transnational actors are unlikely to have knowledge of unpublished decisions. $^{247}$ For domestic court decisions to affect the strategic behavior of transnational actors, those actors must have knowledge of those decisions. ${ }^{248}$ Therefore, the published decisions of domestic courts are likely to have broader global governance implications than those that are unpublished.

The direct consequences of domestic court decisions in particular lawsuits for the parties to those lawsuits are also very important. ${ }^{249}$ Thus, analysis of the transnational shadow of the law is a complement to, not a substitute for, litigant-oriented analysis.

245. See, e.g., Berkowitz et al., supra note 243, at 171 (using International Country Risk Guide data on the quality of domestic legal institutions); Daude \& Stein, supra note 244, at 321-23, 330 (discussing their use of regulatory quality, rule of law, and legal family variables).

246. Clermont \& Eisenberg, supra note 122, at 125-26.

247. Stephen L. Wasby, Unpublished Court of Appeals Decisions: A Hard Look at the Process, 14 S. CAL. INTERDISC. L.J. 67, 96-97 (2004) ("The parties, not the larger legal community, are said to be the primary audience" for unpublished decisions; an unpublished decision " "is, more or less, a letter from the court to parties familiar with the facts,' [in which] only a minimal or truncated fact statement is necessary [and] the law ... need not be stated elaborately," and which " is not written in a way that will be fully intelligible to those unfamiliar with the case." (citing Hart v. Massanari, 266 F.3d 1155, 1176, 1178 (9th Cir. 2001))); Hillel Y. Levin, Making the Law: Unpublication in the District Courts 11 (Jan. 2008) (unpublished manuscript), available at http://papers.ssrn.com/sol3/papers.cfm?abstract $\mathrm{id}=1006101$ ("[U]npublished district court opinions are not meaningfully available for review and study by anyone.").

248. See discussion supra Part II.A. However, it is possible that by deciding not to publish decisions, domestic courts affect the strategic behavior of transnational actors by increasing uncertainty about future court decisions. I thank Christian Ford for pointing this out.

249. See supra text accompanying notes 112-114 (describing these consequences). 


\section{B. Descriptive, Positive-Theoretical, and Normative Goals}

Governance-oriented analysis has descriptive, positivetheoretical, and normative goals. Descriptively, the goal is to shed light on how domestic courts behave as global governors. This is the first step toward improving our knowledge of the contributions of domestic courts to global governance. For example, how often do domestic courts make decisions that allocate global governance authority or determine rights and obligations of transnational actors? How often do domestic courts defer to the authority of foreign states, international institutions, or private institutions rather than asserting domestic state authority? How do the answers to these questions vary over time, cross-nationally, between trial and appellate courts and, within the United States, between state and federal courts? ${ }^{250}$

In terms of positive theory, the goal is to develop and empirically test theories explaining why domestic courts govern the way they do and explaining the transnational shadow effects of their decisions. For example, which factors - both legal and nonlegal - influence whether domestic courts defer to foreign, international, or private authority rather than asserting domestic state authority? Which factors influence how domestic courts determine rights and obligations of transnational actors? In what ways and under what circumstances do domestic court decisions affect transnational activity, the global economy, and the effectiveness of other governance institutions, from international law and international courts, to transnational contracting and transnational arbitration?

Normatively, governance-oriented analysis seeks to evaluate critically the contributions of domestic courts to global governance, with the ultimate goal of comparing these contributions to those of other institutions and identifying the governance arrangements that are

250. The question of cross-national differences is particularly important. The concepts developed in this Article are intended to be sufficiently general to be analytically useful across different legal systems. However, the examples used in this Article are drawn primarily from the U.S. legal system and, to a lesser extent, the EU legal system. Crossnational empirical research will be needed to determine just how well these concepts can travel from state to state. Recent scholarship suggests that the role of domestic courts in global governance extends beyond U.S. courts. See Benvenisti \& Downs, supra note 6, at 380-83 (surveying involvement of national courts inside and outside the United States in fostering democratic accountability in global governance). However, because of the possibility that U.S. courts may exert greater or different influences, generalizations must be made with caution. See Brand, supra note 110, at 115 ("Private litigation is used in the United States in ways not common or even possible in other countries."); Stephen B. Burbank, All the World His Stage, 52 AM. J. CoMP. L. 741, 262 (2008) (noting "unique role of litigation in the United States"). 
most appropriate for different realms of transnational activity. Here, the distinction between transnational legal doctrine and transnational law in action is particularly important, for it provides a lens for evaluating not only what transnational law says, but also how domestic courts apply it to reach real-world outcomes.

The normative questions are many: Is it a good thing that domestic courts play an important role in global governance? ${ }^{251}$ Do domestic courts perform their global governance functions in a cosmopolitan or parochial manner? Do they foster or undermine transnational rule of law? Do their decisions increase or decrease global economic welfare? And what are the implications for fundamental political values such as separation of powers, democracy, and state sovereignty?

In fact, a debate is already emerging over issues like these. On the one hand, Hannah Buxbaum argues that "transnational regulatory litigation can, under proper circumstances, enable national courts to participate in implementing effective regulatory strategies for global markets."252 Likewise, Harold Koh argues that "transnational public law litigation represents a positive development, designed to further the protection of international human rights and to return U.S. courts to their proper, but neglected role, as guardians of international law.",253

Others are less optimistic, arguing that using domestic litigation to address global issues carries substantial costs. For example, Austen Parrish argues that insofar as domestic courts attempt to solve global problems by applying domestic law extraterritorially, they pose significant threats to notions of democratic sovereignty. ${ }^{254}$ Curtis Bradley argues that international human rights litigation in U.S. courts creates significant costs for U.S. foreign relations, U.S. democracy, and the international system. ${ }^{255}$ Tanja Börzel suggests that domestic courts may reinforce the advantages of the "haves" over the "have nots" in transnational relations. ${ }^{256}$

251. A panel coorganized by the author explicitly addressed this question at the Joint Annual Meeting of the Law and Society Association and the Canadian Law and Society Association, Montreal, Canada, June 1, 2008.

252. Buxbaum, supra note 6 , at 316 .

253. Koh, supra note 106, at 3; see also Wai, supra note 6, at 244 ("[T]ransnational litigation of private law claims in national courts could constitute part of a plural regime for the governance of transnational economic activity ....”).

254. Parrish, supra note 44, at 6.

255. Bradley, supra note 16 , at 457-58.

256. Börzel, supra note 182, at 132 (arguing that transnational litigation in domestic courts may be an important tool for vindicating international rights, but those actors who 
The quality of this emerging debate ultimately depends on a sound understanding of how domestic courts actually make decisions in transnational litigation and how those decisions affect transnational activity. The descriptive, positive-theoretical, and normative goals of governance-oriented analysis are thus closely related: the importance of the normative questions reinforces the importance of the descriptive and positive-theoretical endeavors, and the answers to the normative questions depend in part on the knowledge gained in those endeavors.

\section{CONCLUSION}

Domestic courts are global governors. They provide support for transnational activity by allocating governance authority among states, between domestic and international institutions, and between public and private institutions. They also determine rights and obligations of transnational actors. By performing these global governance functions, domestic courts exert an influence that extends beyond the parties to particular lawsuits and beyond borders. Their decisions affect the strategic behavior of transnational actors and global economic welfare. And they can either support or hinder efforts to govern transnational activity through international institutions, such as international law and international courts, and private institutions, such as transnational contracting and transnational arbitration. The effectiveness of these alternative governance arrangements depends significantly on the support of domestic courts.

Yet scholars have devoted relatively little attention to the role of domestic courts in global governance. As a result, we know very little about how domestic courts behave as global governors, why they govern the way they do, and how they affect transnational activity. Governance-oriented analysis - which combines doctrinal analysis with analysis of transnational law in action and blends litigant-oriented analysis with analysis of behavior in the transnational shadow of the law - can help scholars address this gap in knowledge, and develop the empirical foundations needed for a sound debate about the role of domestic courts in the world.

Governance-oriented analysis can also contribute to several existing areas of scholarship. By shedding empirical light on the role of domestic courts in global governance, it can contribute to scholarship that examines alternatives to international institutions as 
mechanisms for regulating transnational activity; ${ }^{257}$ to the emerging body of interdisciplinary international law-international relations scholarship that highlights the importance of domestic actors, ${ }^{258}$ and to research on judicialization, ${ }^{259}$ which so far has explored the role of domestic courts in domestic governance ${ }^{260}$ and international courts in global governance, ${ }^{261}$ but not the role of domestic courts in global governance. By elucidating the role of domestic courts in the allocation of adjudicative, prescriptive, and enforcement authority and in the development and implementation of international law, governance-oriented analysis can contribute empirically to traditional international law and conflict-of-laws scholarship. By showing how domestic courts can facilitate or hinder the effectiveness of international courts, it can contribute to recent scholarship on the emergence of an international judicial system. ${ }^{262}$ And by improving our understanding of the relationship between domestic courts and private forms of governance, it can contribute to research on global legal pluralism. ${ }^{263}$

Most importantly, with improved knowledge of transnational judicial governance, scholars and policy makers can better evaluate the contributions of domestic courts to global governance and compare those contributions with those of other institutions. Ultimately, such knowledge can help identify which governance arrangements are most appropriate for different realms of transnational activity, and which arrangements are best able to maximize the benefits and mitigate the costs of globalization.

257. See, e.g., Pollack \& Shaffer, supra note 24 (comparing interstate, transgovernmental, and private forms of global governance).

258. See, e.g., Kahler, supra note 179, at 674-77 (describing the role of domestic "compliance constituencies" in international legal system); Anne-Marie Slaughter \& William Burke-White, The Future of International Law Is Domestic (or, The European Way of Law), 47 HARV. INT'L L.J. 327 (2006) (same).

259. On the concept of judicialization, see generally HIRSCHL, supra note 7; SHAPIRO \& Stone SweET, supra note 7; THE Global EXPANSION OF Judicial Power, supra note 7.

260. See, e.g., SHAPIRO, supra note 7 (analyzing role of domestic courts in domestic governance); STONE SWEET, supra note 197 (same); Dahl, supra note 7 (same).

261. See, e.g., ALTER, supra note 7 (analyzing role of European Court of Justice in European governance); Sandholtz \& Stone Sweet, supra note 7 (analyzing global governance implications of World Trade Organization and European Court of Justice); COURTS CROSSING BORDERS: BLURRING THE LINES OF SOVEREIGNTY, supra note 7 (general study of role of international courts in world politics). system).

262. See Martinez, supra note 6 (describing emergence of an international legal

263. See generally Paul Schiff Berman, Global Legal Pluralism, 80 S. CAL. L. Rev. 1155 (2007); Ralf Michaels, Global Legal Pluralism, 5 ANN. REV. L. \& Soc. SCI. (2009). 